YEARBOOK

of ANTITRUST

and REGULATORY

STUDIES

www.yars.wz.uw.edu.pl
Peer-reviewed scientific periodical, focusing on legal and economic issues of antitrust and regulation. Creative Commons Attribution-No Derivative Works 3.0 Poland License.

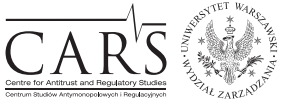

Centre for Antitrust and Regulatory Studies, University of Warsaw, Faculty of Management www.cars.wZ.uw.edu.pl

\title{
The Polish Leniency Programme and the Implementation of the ECN + Directive Leniency-related Standards in Poland
}

\author{
by
}

\author{
Patrycja Szot*
}

\section{CONTENTS}

I. Introduction

II. The ECN+ Directive

III. Leniency programme in the ECN+ Directive

IV. The leniency programme in Poland

V. Implementation of the ECN + Directive's provisions on leniency programmes in Poland

1. Scope of leniency programme

2. Conditions for granting immunity from or reduction of fines

2.1. Method of harmonisation

2.2. Specific conditions for immunity

2.2.1. The concept of relevant evidence and relevant information

2.2.2. Novelty concept

2.2.3. Evidence significantly contributing to finding of an infringement v. sufficient evidence

2.2.4. Scope of the ring-leader exception: coercing v. inducing

2.2.5. Priority requirement: first to submit relevant evidence or first to fulfil all conditions

2.2.6. Duty to confirm the granting of conditional immunity

2.3. Specific conditions for a reduction of fine

2.3.1. Relevant evidence

2.3.2. Lack of rules on fine reduction

2.3.3. Partial immunity

* Patrycja Szot, LL.M., PhD, Warsaw Bar; e-mail: p.szot@lawyer-competition.eu; all views expressed in this article are strictly personal. Article received: 14 August 2019; accepted: 29 August 2019. 
2.3.4. Simultaneous applications for immunity and a reduction of fine

2.3.5. Leniency Plus

2.4. General leniency conditions

2.5. Duty to grant leniency

3. Form of leniency statements and confirmations

4. Marker

5. Summary application

6. Individual sanctions

7. Protection of leniency information

VI. Missed opportunities

VII. Conclusions

\section{Abstract}

This publication discusses the current state of the Polish leniency programme and the amendments required in order to implement the ECN+ Directive (in particular in the area of specific conditions for leniency, individual sanctions, protection of leniency statements or leniency plus) as well as harmonisation flaws (primarily lack of one-stop-shop, universal language, failure to lay down rules regulating the reduction of fines or fully coordinating rules on immunity from individual sanctions, lack of harmonisation regarding applications in non-cartel cases). The author's view is that the Polish system in broad terms corresponds to the majority of the harmonised standards owing to soft harmonisation based on the Model Leniency Programme and the EU leniency programme. Further, the implementation will not bring about revolutionary changes, unless combined with de lege ferenda improvements and enhancements in the general level of anti-cartel enforcement.

\section{Résumé}

Cette publication traite de l'état actuel du programme de clémence en Pologne et des modifications nécessaires pour mettre en œuvre la directive ENC+ (en particulier dans le domaine des conditions spécifiques de clémence, des sanctions individuelles, la protection des déclarations effectuées en vue d'obtenir la clémence ou «Leniency plus»), ainsi que des lacunes en matière d'harmonisation (principalement absence d'organe centralisé, de langage universel, absence de règles régissant la réduction des amendes ou de règles pleinement coordonnées en matière d'immunité des sanctions individuelles). Selon l'auteur, le système polonais correspond globalement à la plupart des normes harmonisées grâce à une harmonisation «douce» fondée sur le programme modèle du REC en matière de clémence et sur le programme de clémence de l'UE. Sa mise en œuvre n'entraînera pas de changements drastiques, à moins d'être combinée à des améliorations de lege ferenda et à une amélioration générale dans le niveau de lutte contre les ententes. 
Key words: $\mathrm{ECN}+$, leniency, Polish leniency, leniency plus, private enforcement, ring-leader, NCA, summary application, marker, individual sanctions, UOKiK, immunity, reduction of fines, enforcement of competition law.

JEL: K21

\section{Introduction}

This publication discusses the current state of the Polish leniency programme and the amendments required in order to implement the ECN + Directive. It is based on a comparative method of analysis. The author's view is that the Polish system in broad terms corresponds to the majority of the harmonised standards, because in many aspects it follows the suggestions of the European Competition Network's (hereinafter: ECN) Model Leniency or the EU model. Nonetheless, a detailed analysis reveals the need for a number of adjustments. Those concern, in particular, the specific conditions that the applicant must meet in order to benefit from immunity or a reduction of fines (with emphasis on the standard of relevant evidence), requirement to provide for immunity from criminal sanctions for individuals or to further limit the use of information derived from leniency statements to specific instances.

The author also briefly discusses de lege ferenda proposals unrelated to the harmonisation, for instance narrowing down the scope of the Polish leniency programme to cartels, hub and spoke arrangements and limited vertical infringements, removing uncertainties regarding the scope of ring leaders included among potential immunity recipients or clarifying some procedural issues. Critical views are expressed in relation to the harmonisation flaws, in particular failure to introduce one-stop-shop or at last an option to use a universal language, or to fully coordinate requirements for immunity from individual sanctions, and lack of rules regulating the reduction of fines or harmonisation regarding applications in non-cartel cases.

The following sections present (i) the main rationale behind the ECN + Directive, (ii) a brief look on the background of the Polish leniency programme and (iii) a discussion of each area subject to harmonisation (following the ECN+ Directive's order), that is, leniency conditions, requirements as to the form, marker, summary application, individual sanctions, protection of leniency information (iv) brief look at the harmonisation flaws and (v) conclusions.

The author's view is that an introduction of immunity for bid-riggers may bring about noticeable effects. Otherwise, the implementation of the $\mathrm{ECN}+$ Directive's rules concerning leniency will not advance the effectiveness of Polish leniency, or overall Article 101 enforcement, in a revolutionary way. 
In this area, in the first place a visible change in approach to enforcement policy is required, in particular increasing enforcement actions against cartels.

\section{The ECN+ Directive}

The ECN+ Directive ${ }^{1}$ was adopted in December 2018. Its objective is to boost the national competition authorities' powers to ensure that EU competition law is effectively applied and enforced across the EU. Following the entering into force of Regulation $1 / 2003^{2}$ on 1 May 2004, national competition authorities (hereinafter: NCAs) have powers and the obligation to directly apply EU competition law (prohibition of anticompetitive agreements and abuse of a dominant position) alongside the EU Commission (hereinafter: Commission). The review of public enforcement showed that this decentralisation has enhanced the enforcement of Union's competition law. ${ }^{3}$ However, the state of affairs was far from ideal and the system's efficiency continued to by undermined by disparities in the enforcement tools available to the NCAs across the EU, differences in substantive law and enforcement practice. ${ }^{4}$ The ECN + Directive's objective is to remove this problem by introducing a set of union-wide minimum standards. The areas addressed comprise guarantees on (i) independence and adequate resources (financial, technical and technological) of the NCAs, (ii) the NCAs' investigative, decision-making and enforcement powers, in particular power to impose fines and periodic penalties, (iii) mutual assistance among the NCAs, (iv) the

1 Directive (EU) No 2019/1 of the European Parliament and of the Council of 11 December 2018 to empower the competition authorities of the Member States to be more effective enforcers and to ensure the proper functioning of the internal market, published on 14 January 2019 (OJ 2019 L 11, p. 3-33), (hereinafter: ECN+ Directive).

2 Council Regulation (EC) No 1/2003 of 16 December 2002 on the implementation of the rules on competition laid down in Articles 81 and 82 of the Treaty (OJ 2003 L 1, p.1), (hereinafter: Regulation 1/2003).

3 See conclusions and recommendations in the Communication from the Commission to the European Parliament and the Council. Ten Years of Antitrust Enforcement under Regulation 1/2003: Achievements and Future Perspectives \{SWD(2014) 230\}_\{SWD(2014) 231\}, (hereinafter: Communication Ten Years of Reg. 1/2003), retrieved from http://ec.europa. eu/competition/antitrust/antitrust_enforcement_10_years_en.pdf (accessed on 30.06.2019) and Proposal for a Directive of the European Parliament and of the Council to empower the competition authorities of the Member States to be more effective enforcers and to ensure the proper functioning of the internal market (Text with EEA relevance) $\{\operatorname{SWD}(2017) 114\}$ \{SWD(2017) 115\} \{SWD(2017) 116\}, (hereinafter: Commission Proposal), retrieved from http://ec.europa.eu/competition/antitrust/proposed_directive_en.pdf (accessed on 30.06.2019).

${ }^{4}$ Infra. Król-Bogomilska, 2018, p. 13-14, discussed in detail the flaws of the current system in the specific context of penalties. 
NCAs' role before national courts and (v) the requirement to comply (while enforcing Article 101 and 102 TFEU) ${ }^{5}$ with general principles of Union law and to respect fundamental rights, in particular the right to defence.

Additionally, a considerable part of the ECN + Directive is dedicated to a core problem of this publication, namely creating a level playing field in respect of programmes providing for immunity from or reduction of fines (collectively hereinafter: leniency programme or LP).

The ECN+ Directive addresses only cases in which EU law is applied (alone or in parallel with domestic competition law). Solely the rules restricting access to leniency statements and settlement submissions, and the use of them, apply also in purely domestic cases. ${ }^{6}$ The Member States have to implement the ECN+ Directive until 4 February 2021.

\section{Leniency programme in the ECN+ Directive}

The Commission, while reflecting on antitrust enforcement under Regulation 1/2003 and the proposal for the ECN+ Directive, noted the general increase of actions against secret cartels and the growing importance of leniency programmes in this respect. ${ }^{7}$ In particular, it emphasised that all Member States (with exception of Malta) introduced leniency programmes, which are to a significant degree aligned with the Model Leniency Programme (hereinafter: MLP). The latter is a 'soft' harmonisation tool developed within the ECN with a view of enhancing effectiveness of domestic leniency programmes by providing a state-of-the-art leniency model. It sets out the core rules of substance and procedure. ${ }^{8}$ The Commission emphasised that the MLP led to the introduction of summary applications into domestic leniency regimes. This measure makes it possible for undertakings that applied for leniency before the Commission to take steps to reserve a place in the

5 Consolidated version of the Treaty on the Functioning of the European Union of 13 December 2007, OJ 2008/C 115/01, (hereinafter: TFEU).

${ }^{6}$ See Article 1(2) and Article 31(3)-(4) of the ECN+ Directive; the latter are discussed in more detail in Section V.7 below.

7 See paras. 78-88 of the Commission Staff Working Document. Enhancing competition enforcement by the Member States' competition authorities: institutional and procedural issues Accompanying the document Communication from the Commission to the European Parliament and the Council Ten Years of Antitrust Enforcement under Regulation 1/2003: Achievements and Future Perspectives $\{\mathrm{COM}(2014) 453\}$ \{SWD(2014) 230\}, (hereinafter: CSWD Enhancing Competition Enforcement), retrieved from http://ec.europa.eu/competition/ antitrust/swd_2014_231_en.pdf (accessed on 30.06.2019) and paras. 39-40 of the Communication Ten Years of Reg. 1/2003.

8 The MLP was endorsed in 2006 and revised in 2012. 
queue before a NCA by filing a simplified application, should the Commission ultimately refrain from pursuing the case (or part of it). ${ }^{9}$ Hence, a summary application (if completed) alleviates the burden of multiple simultaneous (full) applications and provides some response to the ever reoccurring problem of the lack of a one-stop-shop system for leniency applications in the EU.

Nonetheless, the Commission made important points about the deficiencies of the current situation. In the first place, it stressed that sufficient legal certainty concerning the leniency status is a key factor determining undertakings' willingness to report cartels. In this context, the multijurisdictional nature of cartels (cartels often extend beyond national borders) requires creating a level playing field for potential leniency applicants across the EU. Otherwise deficiencies of a single (national) leniency programme(s) may undermine the collective effectiveness of the entire EU leniency-based enforcement. ${ }^{10}$ Possible applicants need to be assured that their decision to come forward to the Commission or a particular NCA will not expose them or their staff to severe fines in another Member State. Such situation may arise if leniency advantages are not available in another Member State or because they offer substantially different levels of protection. ${ }^{11}$ Against this background, the Commission noted that while the leniency programmes currently in force achieved a certain level of alignment, ${ }^{12}$ differences continue to subsist. In particular, the conditions under which leniency is available very and not all

${ }^{9}$ Summary applications can be submitted with respect of cartels affecting at least three Members States. For a more detailed discussion of this institution see Section V.5 below and Gauer and Jaspers, 2007, p. 37.

10 See Section 2.2.3. of the Commission Staff Working Document Impact Assessment accompanying the document Proposal for a Directive of the European Parliament and of the Council to empower the competition authorities of the Member States to be more effective enforcers and to ensure the proper functioning of the internal market $\{\mathrm{COM}(2017) 142\}$ \{SWD(2017) 115\} \{SWD(2017) 116\}, (hereinafter: Impact Assessment Report), retrieved from http://ec.europa.eu/competition/antitrust/impact_assessment_report_en.pdf (accessed on 30.06.2019). Hansberry-Bieguńska, Krasnodębska-Tomkiel and Materna, 2016, p. 34 emphasise that differences between national LPs undermine effectiveness of those programmes. See for a detailed discussion of typical differences by Król-Bogomilska, 2012, p. 7-9.

11 More importantly these decisions are weighted against the risk of liability for damages, albeit reduced to certain extent by Article 11 (4) to (6) of the Directive (EU) No 2014/104 of the European Parliament and of the Council of 26 November 2014 on certain rules governing actions for damages under national law for infringements of the competition law provisions of the Member States and of the European Union (OJ 2014 L 349, p. 1-19), (hereinafter: Damages Directive).

12 It is worth noting that in the documents relating to the assessment of the ten years of competition enforcement under Regulation 1/2003, the Commission refers to a 'significant process of alignment' of national leniency programmes with the MLP (see para. 80 of the CSWD Enhancing competition enforcement). Later however, in the documents setting out the rationale behind the proposal for ECN + Directive, the language is less positive. In there, the Commission 
NCAs accept summary applications. ${ }^{13}$ More importantly, however, there are no legal guarantees that existing convergence will not be lost. This is because there is no requirement under EU law to maintain at a national level leniency programmes applicable to Article $101 \mathrm{TFEU}$ infringements. ${ }^{14} \mathrm{In}$ the same vein, the Member States are not under an obligation to incorporate the MLP rules into domestic laws, ${ }^{15}$ including to honour summary applications concerning cartels affecting more than one territory.

Secondly, there are significant differences regarding the protection of leniency and settlement material. The Commission pointed to such examples as availability (in some Member States) of leniency statements to public prosecutors and/or the police with a view of using it in proceedings unrelated to enforcement of EU competition law or to civil courts for purposes other than private enforcement. ${ }^{16}$

Thirdly, the Commission emphasised that the lack of convergent standards on protecting staff employed by the applicants deters undertakings from reporting cartels. At the same time, it hinders such undertakings' ability to collect relevant information and evidence with a view of preparing leniency applications. Employees facing potential individual sanctions may be unwilling to cooperate or may be tempted to destroy evidence pointing to their involvement in an infringement and hence potential liability. An important risk-enhancing factor is that an employee may be held accountable in any Member States affected by the cartel, not only the one where its company applied for leniency. This circumstance multiplies the need for harmonisation of the rules governing the interplay between corporate leniency and individual sanctions.

stated that the non-binding MLP achieved only 'some degree of convergence' (see the Impact Assessment Report, p. 24).

13 See Impact Assessment Report, p. 24.

14 See para. 40 of the Communication Ten Years of Reg. 1/2003.

15 As confirmed in judgment of 20 January 2016, Case C-428/14 DHL Express (Italy) S.r.l. and Others v Autorità Garante della Concorrenza e del Mercato and Others, ECLI:EU:C:2016:27, where it was held that the MLP as a soft harmonisation measure adopted within the framework of the ECN is not binding upon the Member States. Hence they may put in place leniency programmes diverging from it. In this case DHL applied for leniency to the Commission and in Italy. The scope of these applications differed in that one of the markets was not included in the application to the Italian competition authority. The later market was covered by the application of another undertaking that eventually benefited from full immunity in this respect whereas DHL could not (because it was not the first to report the infringement on this particular market). Similarly, in the earlier Pfleiderer case, the Court of Justice (CJEU) pointed out that neither the MLP nor the Commission leniency notice have binding effect at national law (judgment of 14 June 2011, Case C-360/09 Pfleiderer v Bundeskartellamt, ECLI:EU:C:2011:389, para. 21-22); see also Kulesza, 2015, p. 93 and critical comments relating to judgment by Stephan, 2011.

16 See Impact Assessment Report, p. 24. 
In light of the above consideration the Commission proposed to harmonise the leniency programmes by transposing the main principles of the MLP into the ECN+ Directive. Hence, the following issues have been addressed in the ECN + Directive eventually adopted by the European Parliament and the Council: (i) obligation to provide for a leniency programme, (ii) conditions for immunity from and reduction of fines, including instructions regarding the duty of cooperation, (iii) form of leniency statements, (iv) markers, (v) summary applications, (vi) interplay between immunity applications and sanctions on natural persons and (vii) protection of leniency materials. The requirements concerning transposition and implementation of those rules into the Polish legal system are discussed in the same order in Section V below (it corresponds to the order adopted in the ECN+ Directive).

\section{The leniency programme in Poland}

Poland introduced its first leniency programme ${ }^{17}$ on the day it accessed the EU (1 May 2004). ${ }^{18}$ It was modelled on the 2002 Commission leniency notice. ${ }^{19}$ The provisions of the first leniency programme have been subsequently transferred into the new Act on Competition and Consumer Protection of $2007^{20}$ without any substantial change (Molski, 2014, s. 1405) and any reference to the 2002 Commission Leniency Notice (Korycińska-Rządca, 2018, p. 65)

17 Commentators consider that Article 89 of the Act of 15 December 2000 on Competition and Consumer Protection (consolidated text: Journal of Laws 2003, No. 86, item 804; hereinafter: 2000 Competition Act) could not qualify as a leniency programme due to its limited application (cartels were outside its scope) and because the undertaking could plead guilty only if called to do so by the competition authority (Turno, 2013, p. 361; Kulesza, 2015, p. 85 - 86).

18 Act of 16 April 2004 Amending the Act on Competition and Consumer Protection and Certain Other Acts (Journal of Laws 2004, No. 93, item 891; hereinafter: 2004 Amendment. This law amended the 2000 Competition Act.

19 Commission notice of 19 February 2002 on immunity from fines and reduction of fines in cartel cases (OJ 2002 C 45, p. 3), hereinafter: 2002 Commission Leniency Notice, available at: https://eur-lex.europa.eu/legal-content/EN/ALL/?uri=CELEX:52002XC0219(02) (30.06.2019). The justification of the draft legislation clarified that the 2004 Amendment's aim was to implement rules 'analogues' (hence not identical) to the ones set out in the 2002 Commission Leniency Notice (see IV term Sejm paper No. 2561, p. 38, available in Polish at: http://orka. sejm.gov.pl/Druki4ka.nsf/wgdruku/2561/\$file/2561.pdf (30.06.2019).

20 Act of 16 February 2007 on Competition and Consumers Protection (consolidate text: Journal of Laws 2019, No. 369), hereinafter; 2007 Competition Act. The provisions were not adjusted to the updated Commission notice of 8 December 2006 on immunity from fines and reduction of fines in cartel cases (OJ 2006 C 298, p. 17), hereinafter: 2006 Commission Leniency Notice, available at: https://eur-lex.europa.eu/legal-content/EN/TXT/PDF/?uri=CELEX:52006

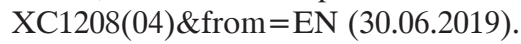


or adopting the principles set forth in the MLP (2006 version). The Polish leniency programme (hereinafter also: PLP) was partly adjusted to the MPL in 2009 by force of a Regulation of the Council of Ministers (a lower-rank legislative act) ${ }^{21}$ and non-binding leniency guidelines. ${ }^{22}$ This development spurred criticism because the 2009 Procedural Regulation exceeded the scope of the legislative authorisation by laying down requirements for leniency applications and modifying leniency conditions. ${ }^{23}$ In any case, neither the documents of this rank, nor the non-binding notice, was the appropriate way to impose new obligations on undertakings (Król-Bogomilska, 2010, p. 12; Kulesza, 2015, p. 96 and literature cited therein).

This 2009 leniency programme was substantially amended in $2014^{24}$ to match the updated (in 2012) version of the MLP among others (Kulesza, 2015, p. 96). ${ }^{25}$ The 2014 Amendment also sorted out some of the above

21 The rules on the leniency procedure were set out in the Regulation of the Council of Ministers of 26 January 2009 on the procedure pertinent to applications filed with the President of the Competition and Consumer Protection Office for immunity or reduction of fine (Journal of Laws 2009, No. 20, item 109), hereinafter: 2009 Procedural Regulation.

22 The Leniency Guidelines of the Polish Competition Authorities' President, applicable as of 24 February 2009; hereinafter: 2009 Polish Guidelines. Available in Polish at: www.uokik. gov.pl/aktualnosci.php?news_id=526 (30.06.2019).

${ }^{23}$ For instance, markers and summary applications, introduced by that regulation, were not foreseen in the 2007 Competition Act (a higher-rank act). Yet, by effectively modifying the rules on priority, they could deprive the undertakings that considered from the outset submitting a full leniency application of the right to benefit from immunity (because marker or summary applicants would be better placed in an immunity queue); critically Król-Bogomilska, 2010, p. 12-13, Król-Bogomilska, 2012, p. 10. Those provisions have been subsequently incorporated into the 2007 Competition Act (see comments further down)., which improved the situation from the perspective of proper legislation. However, this does not change the fact that marker option in principle places more diligent applicants (submitting full application in the first place) in disadvantageous position.

24 See the Act of 10 June 2014 Amending the Competition and Consumers Protection Act and the Civil Procedure Code (Journal of Laws 2014, No. 945, hereinafter: 2014 Amendment. The new rules have been supplemented by the Regulation of the Council of Ministers of 23 December 2014 on the procedure pertinent to applications for immunity or reduction of fine (Journal of Laws 2015, item 81), hereinafter: 2014 Procedural Regulation that replaced the 2009 Procedural Regulation.

25 The justification of the draft 2014 Amendment pointed to the MLP and experience of other jurisdictions to explain the reasons for which strict requirement to end infringement on the day the infringer submitted application was replaced (by a more lenient requirement) to end involvement in such infringement immediately following the leniency application at the latest. The MLP is also mentioned to justify the decision to include the initiator of an infringement among potential beneficiaries of immunity. Additionally, the Polish NCA relied on the MLP to substantiate its responses to comments provided within the framework of the draft legislation public consultation process. See: (VI term Sejm paper No. 1703, p. 70, 127), available in Polish at: http://www.sejm.gov.pl/Sejm7.nsf/druk.xsp?nr=1703 (30.06.2019). 
controversies by incorporating into the 2007 Competition Act certain provisions of the 2009 Procedural Regulation. The law is supplemented by updated leniency guidelines. ${ }^{26}$ It is argued that the Polish leniency rules currently in force correspond to the MLP (2012) and are a result of 'soft harmonisation'. ${ }^{27}$ Nonetheless, a number of differences between the Polish system and the ECN's model (MLP) persists (Kulesza, 2015, p. 97, Korycińska-Rządca, 2018, p. 68-77). The ECN+ Directive transposes the main principles of the MLP, hence those divergences will have to be addressed in the implementation process.

\section{Implementation of the ECN + Directive's provisions on leniency programmes in Poland}

\section{Scope of leniency programme}

Pursuant to the ECN+ Directive, each NCA should have in place a leniency programme applicable at least with respect to secret cartels with the EU dimension. ${ }^{28}$ The Member States may, but do not have to, foresee leniency programmes applicable to other Article 101 TFEU infringements (and its national equivalents) or to natural persons. ${ }^{29}$

The PLP covers all practices infringing Article 101 and its Polish equivalents (cartels, and other horizontal restrictions, for instance commercialisation or standardisation agreements as well as vertical restrictions) ${ }^{30}$ and it provides for a possibility to extend the leniency benefits onto natural persons. In this

26 The Leniency Guidelines of the Polish Competition Authorities' President dated May 2017, hereinafter: 2017 Polish Guidelines. Available in Polish at: t http://www.uokik.gov.pl/ download.php?plik=9486 (30.06.2019).

27 I.e. voluntary harmonisation (as opposed to legislative or judicial harmonisation). Kowalik-Bańczyk, 2014, p. 147-148 explains the concept in detail and how it is applied in the area of competition law.

28 The definition of a secret cartel is provided in Article 2(11-12) of the ECN+ Directive. References in this publication to a 'cartel' should be understood as references to a 'secret cartel' unless stated otherwise.

${ }^{29}$ See Article 17(1) and 18(1) of the ECN+ Directive. See comments in Section V.6 below concerning availability in Poland of leniency options to natural persons.

30 See Article 113a and 4(5) of the 2007 Competition Act. Kulesza, 2015, p. 87, considers that this might be a result of a misunderstanding rather than a well-thought policy decision to broaden the scope of the leniency programme, i.e. the Polish NCA while drafting the first leniency rules in 2004 relied on an overly broad definition of cartels referring to any agreements restricting competition that was used in the Polish NCA's 2004 brochure entitled Leniency. 
respect it differs from the MLP which is limited to secret cartels, including hub and spoke arrangements. ${ }^{31}$ In the light of the final wording of the ECN + Directive, Poland does not have to narrow down the PLP's current scope. ${ }^{32}$ Therefore views to the contrary, based on the earlier drafts of the ECN+ Directive (Materna, 2018, p. 44), lost importance. ${ }^{33}$ Nonetheless, the question of whether Poland should consider limiting the scope of the PLP to cartels, hub and spoke arrangements and very limited vertical restraints at the most, remains valid. ${ }^{34}$ It is considered that leniency benefits should not apply to restrictions other than cartels because the former are normally less difficult to detect or investigate with use of standard powers (inspections, information requests, complaints from market participants, open-source intelligence, etc). In particular, in the context of vertical restraints, potential infringers' interests are usually divergent, hence there is no element of solidarity that needs breaking by exceptional means such as leniency. Moreover, the legal assessment of vertical restraints or non-cartel arrangements is not straightforward (Molski, 2014, p. 1407; Sitarek, 2014, p. 209, 210). For instance, economic considerations that play an important role in such assessment, at the end of the day often alter the initial conclusions in favour of the restriction. A broadly applied leniency system may therefore transform into an informal clearance scheme, which would be an unwelcome development (see MLP, 2006, p. 11). ${ }^{35}$ In any

31 Similarly to the majority of the national LPs in the EU, see Rumak, Sitarek, 2009, p. 103, Król-Bogomilska, 2015, p. 7; Piszcz, 2016, p. 214 (who discusses examples of approaches taken in other jurisdictions) and Korycińska-Rządca, 2018, p. 68.

32 The ECN+ Directive explicitly states now that the requirement to put in place LPs applicable to secret cartels is without prejudice to national provisions on leniency programmes applicable to other infringements (Article 17(1), 18(1) and Recital (11) of the ECN+ Directive. Similar option was foreseen already in the Commission Proposal, however only in recitals (recital number 10), which in fact also mentioned the possibility of extending such programmes to the abuses of a dominant position (Article 102 TFEU and equivalent national provisions).

33 Albeit not entirely, see the extended reading of this interpretation in section V.2 below. Król-Bogomilska, 2018, p. 20 argued that Poland could preserve the current status quo and continue to extend leniency to non-cartel infringements (of Article 101 TFEU and its national equivalents) also based on the earlier drafts of the ECN + Directive precisely because those drafts failed to address in whatsoever manner the issue of LPs' possible broader application.

34 This opportunity was missed on the occasion of the 2014 Amendment (Piszcz, 2016, p. 214; Skoczny, 2015, p. 170).

35 Turno, 2013, p. 460-465, advances similar arguments in criticism of the broad scope of the PLP's application. He additionally emphasises that such approach undermines the system's deterrent effect and effective operation, i.e. leads to low number of applications and infringement decisions. In the period 2004-2019 (until 26 September 2019) in total 83 applications were submitted (according to information provided by the Polish NCA on the author's request). Poland was placed in the second from the top group of Member States in terms of a number of applications received in years 2004-2014 (Annexes to the Impact Assessment Report, available at: http://ec.europa.eu/competition/antitrust/nca.html (30.06.2019). Unfortunately, 
case, vertical restraints are in principle less harmful than cartels. The idea of extending leniency benefits to let wrongdoers go unpunished, without gaining clear and crucial benefits, does not sit comfortably with the consideration of natural justice. ${ }^{36}$ In view of these considerations, an overly broad scope of a LP's application may undermine the effectiveness of EU competition law enforcement in contravention of the Schenker ruling ${ }^{37}$ (Sitarek, 2014, p. 208,210$)^{38}$ in the same way as overly lenient application of LPs may weaken the whole system. ${ }^{39}$

In light of the above, it is submitted that Poland, on the occasion of the $\mathrm{ECN}+$ Directive's implementation, limits the application of its LP to cartels, including hub and spoke arrangements and to vertical price-fixing and bid-rigging at the most. ${ }^{40}$ In this case, it would be necessary to introduce into the 2007 Competition Act a definition of a cartel (and secret cartel) corresponding to Article 2 (11-12) of the ECN+ Directive. In this way, the

Poland's relatively good result can be traced back to applications made with respect to vertical cooperation. The majority of the Polish NCA decisions based on leniency applications related to vertical restraints, see Turno, 2013, p. 624-648 (in particular pricing agreements, the author discussed decisional practice spanning from 2004 to 2012), Hansberry-Bieguńska et al., 2016, p. 53, citing the relevant decisions in footnotes 150 and 151; Skoczny, 2015, p. 170; Turno, 2016, p. 1483).

36 In those situations, the benefits might not outweigh disadvantages, as it is the case in LPs applied to cartels where the interest of consumers in ensuring that secret cartels are detected and punished is balanced against the interest in imposing fines on those undertakings who made cartel discovery possible (2009 Commission Leniency Notice, para. 3). '[A]rgumentation based on natural justice should not lead to the creation of a scheme which is neither just nor effective' (Rumak, Sitarek, 2009, p. 104).

37 Judgment of 18 June 2013, Case C-681/11 Bundeswettbewerbsbehörde and Bundeskartellanwalt v Schenker \& Co. AG and Others, ECLI:EU:C:2013:404, hereinafter: Schenker. In Schenker, the CJEU held that infringements of Article 101 TFEU may be left unpunished based on national leniency programmes only exceptionally and provided there is no harm to the uniform and efficient enforcement of this Article (para. 46, 47 and 49 of Schenker, see detailed comments Sitarek, 2014, p. 206-207).

38 The broad scope of the PLP's application was assessed positively by Soltysiński, 2004, p. 41. Hansberry-Bieguńska et al., 2016, p. 23 also note that the broad scope of the PLP's application led to the discovery of many harmful infringements. However, this is illustrated by an example of hub-and-spoke type of arrangements with inherent horizontal effects (decisions of the Polish NCA no DOK 107/06 of 18.09.2006, DOK-4/2010 of 24.05.2010 and DOK-12/2010 of 31.12.2010).

39 The system may be self-detrimental if the leniency benefits are easy to obtain, in particular including during or after the inspection and even if the authority collected a compelling piece of evidence. In such a situation, the undertakings are unwilling to report because they may avoid fines by coming clear as late as when opening the door to the inspectors.

40 A similar compromise has been endorsed also in the literature, e.g. Turno, 2013, p. 461; Turno, 2016, p. 1487 (who emphasises also that the UK's system is based on the same approach); Molski, 2014 p. 1408 (in favour of hub and spoke only). 
list of infringements covered by leniency could simply refer to 'cartels' next to a few vertical restraints proposed above..$^{41}$

\section{Conditions for granting immunity from or reduction of fines}

\subsection{Method of harmonisation}

The ECN+ Directive specifies the conditions under which immunity from fines or a reduction of fines can be granted (Article 17 to 19). In this respect, the wording of the relevant provisions becomes more demanding, as it is stipulated that the Member States shall ensure that immunity from and a reduction of fines is granted only where the applicant fulfils the conditions set out in Article 17(2) and 18(2) of the ECN + Directive. The ECN+ Directive is primarily based on the minimum and non-exhaustive harmonisation approach (Monti, 2017, p. 8; Rusu, 2017). The language used in Article 17(2) and 18(2) suggests, however, that the Member States are not allowed to 'gold-plate' the assumed standard (Rusu, 2017; Materna, 2018, p. 37, 44, the same approach seems to be endorsed by Dobosz, Scheibe, 2017, p. 99 and Król-Bogomilska, 2018 , p. 20). Materna came to the above conclusion by analysing this language in the context of the allowed scope of LPs. As explained in Section V.1. below, at a later stages of the legislative process a clear disclaimer was added regarding the Member States' rights to provide for broader application of LPs. This clarified the situation only half-way, as the remaining text continues to require that leniency benefits are available only under conditions specified in the ECN+ Directive.

Hence, the question is whether the ECN+ Directive's premise is that national LPs applicable to cartels should provide for uniform requirements, whereas the Member States enjoy more or complete flexibility in cases of other infringements. Such approach appears inconsistent. The relevant Recital 11 of the ECN + Directive does not bring much clarity to the issue either. It refers to 'clearer and harmonised rules for leniency in the area covered by [the] Directive' without specifying the nature of harmonisation (minimum or maximum). It also perceives marked (but not any) differences between them as an obstacle to better operation. However the context of this recital is very suggestive. Recital 11 opens by the following statement: 'Conversely,

41 The term 'cartel' (but not a 'secret cartel') has been already defined in the same way in the Article 2(3) of the Act of 21 April 2017 on actions for damages for infringements of competition law (Journal of Laws 2017, item 1132), hereinafter: Damages Act, implementing the Damages Directive. The 2007 Competition Act's status is similar to the status of an act codifying a particular branch of law and therefore it should include all systemic definitions that come within its realm. 
detailed rules are necessary in the area of conditions for granting leniency for secret cartels.' This sentence juxtaposed with the preceding Recital 10 (that obviously refers to minimum harmonisation) suggests that in relation to leniency a maximum harmonisation approach applies. ${ }^{42}$ The supposition is reinforced by the language of Recital $51^{43}$ and Article 17(2) and 18(2)). Hence, the conclusion is that the Member States should implement uniform (set forth in Article 17(2) and 18(2) and 19 of the ECN+ Directive) conditions for granting leniency for secret cartels where maximum harmonisation applies ${ }^{44}$ and may depart from those standards in cases of non-cartel infringements (if they opt for an extended application of their LPs). ${ }^{45}$

\subsection{Specific conditions for immunity}

Pursuant to the ECN+ Directive, in order to be eligible for immunity from or a reduction of fines an applicant must fulfil a set of specific and a set of general conditions. Specific immunity conditions differ from specific conditions for a reduction of fines. The general conditions are common for both types of leniency applications and for this reason are discussed later (Section V.2.4. below).

A successful immunity applicant must fulfil the following specific conditions (Article 17(2) of the ECN + Directive): (a) not have coerced (or taken steps to coerce) others to join or remain in the cartel and (b) be first among the cartel

42 Similar conclusion can be reached based on the French language version. Polish and German language versions are less conclusive in this respect. Alternatively, this phrase can be also understood as merely arguing that minimum standards with respect to conditions for leniency should be more detailed than minimum standards applicable in the area discussed in recital 10 .

43 ' $[. .$.$] It is therefore appropriate to increase legal certainty for undertakings in the internal$ market and to boost the attractiveness of leniency programmes across the Union by reducing these differences by enabling all NCAs to grant immunity and reduction from fines and accept summary applications under the same conditions. Further efforts by the European Competition Network to align leniency programmes could be needed in the future', emphasis added.

44 This view was endorsed by E. Aresnidou (the Commission's representative from DG Competition) during the Polish - German Academic Conference concerning the ECN+ Directive, held at Warsaw University on 17 October 2019.

45 Bearing in mind considerations set out in Section V.1. (risk of undermining the effectiveness of Article 101 TFEU enforcement), a departure from the directive's standard should be towards more stringent requirements only. Another words, the leniency benefits should not be applicable in overly relaxed manner. Król-Bogomilska, 2018, p. 20, emphasised that differences (across the EU) between LPs applicable to non-cartel infringements might have equally deterrent effect on the undertakings willingness to report as in case of cartels. Hence, by allowing those differences to subsist, the ECN + Directive objective to enhance enforcement of competition law is weakened. 
participants to submit relevant evidence. The threshold of relevant evidence is met if the applicant provides the evidence that:

(i) enables the NCA to carry out a targeted inspection, or (if the NCA already had in its possession evidence sufficient in that regard or had already carried out a targeted inspection $)^{46}$

(ii) an evidence sufficient (in the NCA's view) to find an infringement, provided that the NCA did not yet have in its possession an evidence sufficient in that regard and that no other undertaking previously qualified for immunity pursuant to point (i) (i.e. by providing evidence enabling a targeted inspection to take place).

The PLP does not correspond to some of these requirements. ${ }^{47}$

\subsubsection{Concept of relevant evidence and relevant information}

In the first place, the Polish concept of relevant evidence is based on the 2002 Commission Leniency Notice. Secondly, also submitting relevant information (not evidence) may qualify for immunity (but not a reduction of fines), provided other conditions are met (Molski, 2014, p. 1416; Korycińska-Rządca, 2018, p. 70). ${ }^{48}$ In Poland (in the context of immunity applications), two alternative thresholds for relevant evidence apply (Article 113b(2) of the 2007 Competition Act): it is the evidence that (i) enables the Polish NCA to launch a full-fledged investigation ${ }^{49}$ or (ii) which significantly contributes to finding of an infringement ${ }^{50}$ (if such investigation was already launched). In each of these cases, the relevant information is the one that enabled the Polish NCA to collect relevant evidence. That 'evidence' or 'information' must be new to the Polish NCA.

46 The time when the NCA receives the application is relevant to assess the value of such evidence in this respect.

47 For the English language version of the 2007 Competition Act the reader is kindly referred to the Polish NCA's official site: https://www.uokik.gov.pl/competition_protection.php (30.06.2019).

48 In order to facilitate further analysis, Annex 1 contains a tabular comparison of the PLP's and the ECN+ Directive's requirements concerning relevant evidence and relevant information in the context of applications for immunity and a reduction of fines.

49 As opposed to a 'preliminary investigation' which the Polish NCA may launch in Poland. Formally there are no parties to a preliminary investigation because, at least in theory, it is not directed at specific undertakings. A preliminary investigation may but does not have to precede a full-fledged investigation. The latter corresponds in broad terms to a typical enforcement investigation (Article 47 of the 2007 Competition Act).

50 According to para. 17 and 14 of the 2017 Polish Guidelines it is an evidence that represents significant added value for the purposes of proving an infringement and is relative to the evidence already in the Polish NCA's possession, meaning that it proves certain facts and increases the level of detail of that information. 
The above rules will have to be amended in order to correspond to the requirements of the ECN+ Directive. The standard for the relevant evidence (defined in respect of threshold one) should be modified to the 'evidence that enables a targeted inspection' (and not 'institute an investigation'). ${ }^{51}$ These are two different procedural developments, even if at the end of the day the scope of information required to substantiate such evidence is comparable. ${ }^{52}$ In practice, and according to paragraphs 13 and 16 of the 2017 Polish Guidelines, an evidence (or information) enabling the Polish NCA to instigate an investigation is the evidence that enables a targeted inspection or the launch of a full-fledged investigation..$^{53}$ Turno, 2016, p. 1514, proposed that in the latter case, the threshold of relevant evidence could be met even if it corresponds at least to the standard notification of an infringement that any market participant may submit to the authority (Article 86 (2) 1-5 and 86(3) of the 2007 Competition Act. However, the standard notification may contain very laconic information on the facts. Hence, in principle the leniency applications should be more substantiated.

Hansberry-Bieguńska et al., 2016, p. 33 refers to evidence enabling a targeted inspection as a subcategory of evidence allowing the Polish NCA to open an investigation. ${ }^{54}$ Material indicating the place where other evidence significant for the establishment of an infringement is located, and hence where the search should take place, is a good example of the former. The particular significance of this specific type of evidence steams from the ever increasing role of safeguards in respect of fundamental rights, including prohibition to conduct fishing-expeditions (Hansberry-Bieguńska et al., op. cit). It also may significantly contribute to substantiating a request for a court authorisation to conduct an inspection. ${ }^{55}$

51 Para. 8 if the 2006 Commission Notice was upgraded in a similar way, which also corresponds to para. 5 of the MLP.

52 In the light of para. 9 of the 2006 Commission Leniency Notice, para. 6 of the MLP and Article 19 (b) of the ECN+ Directive, on the one hand, and Article 113a (2) of the 2007 Competition Act, on the other. See for more details Section 2.4. below and Turno, 2016, p. 1515.

53 Additionally, the 2017 Polish Guidelines clarify that it concerns the evidence that confirms the statements regarding the existence of an infringement contained in the application (para. 12 of the 2017 Polish Guidelines).

54 Depending on the circumstances (more precisely, on the results of the inspection), evidence enabling a targeted inspection may be more or less valuable for advancing the case than evidence enabling the opening of an investigation.

55 In Poland judicial authorisation is always required to carry out an inspection in private premises, land or means of transport (see Article 7(2) and 91 of the 2007 Competition Act; the former makes such requirement mandatory). To the author's best knowledge the Polish NCA has not yet searched private premises. Otherwise, judicial authorisation is not compulsory but, if granted, it enables the inspectors to collect evidence independently of consent, assistance or cooperation of an undertaking subject to such forced inspection. In cases of unauthorised 
Additionally, it should be made clear that providing the Polish NCA with relevant information is not enough to benefit from immunity. In other words, it must be necessary to substantiate the application with a concrete piece of evidence to qualify for immunity, which normally should be accompanied by supporting information. The ECN+ Directive (similarly to the MLP) requires that the undertaking furnishes ready evidence which is sufficient to achieve the objectives specified in Article 17(2)(c) and additionally insider information. The expectation pursuant to the PLP rules currently in fore is to some extent similar ${ }^{56}$, but it must be clearly set out in binding law to enhance certainty and transparency. Moreover, the scope of the relevant information required for threshold one and two overlaps. It is considered that in both cases it can be information that permits the authority to collect evidence enabling a targeted inspection. ${ }^{57}$ This approach is inconsistent. It contradicts the assumption (behind the MLP ${ }^{58}$ and hence the ECN + Directive) that immunity is easier available under the lower threshold. In other words, the obligations of an infringer that 'enabled' a targeted inspection are easier to meet than the obligations in threshold two. This is to create an incentive to cease and report an unknown cartel as quick as possible.

The last comment in the context of the relevant information requirement also relates to threshold two. Pursuant to the current wording, the applicant furnishes the relevant information on the Polish NCA's request. ${ }^{59}$ If the application would have to be based exclusively on the relevant information, it simply does not make sense to expect that such information is provided on the authorities' request. In this context, removing the requirement to provide the relevant information altogether would eliminate this inconsistency.

inspection, cooperation of the inspected entity is indispensable (Article 105n of the 2007 Competition Act; Turno, 2016, p. 1367-1368). This steams from the fact that an inspection in Poland may have two forms: control or forced search (inspection) (Polish: kontrola and przeszukanie). The prevailing practice is that the Polish NCA seeks judicial authorisation and conducts forced inspection.

56 Owing to the comparable scope of information generally required, see comments in footnote 53 above.

57 Nonetheless, in practice inspections are rarely conducted after the full-fledged investigation was instituted. Turno, 2016, p. 1517, proposed that information that enabled the authorities to send 'targeted' information requests would be the other example of information required to satisfy threshold two. The 2017 Polish Guidelines does not clarify what the relevant information for the purposes of threshold two is, it addressed this requirement only with respect to threshold one (in detail in para. 13 and in para. 16).

58 See para. 18 of the MLP explanatory notes.

59 See Article 113b (2) item b (towards the end). No such condition is provided with respect to threshold one for the relevant evidence or information (Article 113b (2) item a). 


\subsubsection{Novelty concept}

The PLP's requirement relating to the novelty of the evidence also should be reformulated for the purposes of the implementation. Following the literal interpretation of Article 113b(2) in fine, in Poland the applicant is required to submit the evidence (or information) that was not in the Polish NCA's possession. Technically, it means that an applicant is successful where it submits new evidence (or information) that is sufficient to institute an investigation or find an infringement, even if the Polish NCA at the time of the submission was already in possession of other evidence meeting the same objective ${ }^{60}$ (Molski, 2014, p. 1416 expressed a different opinion, namely that the Polish NCA must not possess at that time sufficient evidence; this is how this requirement is interpreted in practice).

The ECN+ Directive's standard is clearly high in that regard. It concentrates on new and sufficient evidence, instead of merely new evidence. According to this requirement, the NCA must not be in possession of an evidence sufficient to conduct a targeted inspection or find an infringement, which does not necessarily have to be the same as the evidence offered by the applicant (Article 17(c)(i)-(ii)).

The 2017 Polish Guidelines attempted to remove the above shortage of the PLP by clarifying in paragraph 17 that the relevant evidence and information should not only be new but also represent a significant added value relative to materials already in the Polish NCA's possession. This explanation concerns only the threshold two requirements, but probably was intended to have a broader application. In the interest of transparency and certainty, the wording of relevant PLP's provisions should be corrected to unequivocally reflect the above, even if the Polish NCA's practice may follow the approach set out in the ECN+ Directive. This is the more so because the practice may always change. Additionally, the competing applicant may argue for a literal interpretation of current provisions in case of a dispute who should be better placed in an immunity queue.

\subsubsection{Evidence significantly contributing to finding of an infringement $v$. sufficient evidence}

Conversely to the PLP, the ECN+ Directive does not require that the evidence that enables the finding of an infringement (threshold two), contributes to this outcome in a 'significant' way. It is enough if the evidence provided is sufficient

60 Article 113b(2) in fine of the 2007 Competition Act reads as follows: 'provided that the Polish NCA was not in possession of that evidence or information'. It should at least be changed to 'provided that the Polish NCA was not in possession of such evidence or information'. 
to issue an infringement decision. ${ }^{61}$ Even if in practice the interpretation of these terms may point to converging results, the wording of the PLP should be aligned with the ECN+ Directive in the interest of clarity and certainty.

Moreover, the perception of the 2017 Polish Guidelines of the relevant evidence required for the purposes of threshold two is almost the same as in the case of evidence required for a reduction of fines. Resigning from the condition that evidence (information) under immunity 'threshold two' should contribute in a significant way towards finding of an infringement and adapting the ECN+ Directive's approach, would help to differentiate the two requirements.

\subsubsection{Scope of the ring-leader exception: coercing $v$. inducing}

Fifthly, the scope of the ring-leader exception provided in the PLP is broader compared to the ECN + Directive (and the MLP, paragraph 8 or 2006 Commission Leniency Notice, paragraph 13). Hence it needs adjusting. The PLP refers to an undertaking that was inducing (convincing) others to participate in an infringement (Article 113b(3) of the 2007 Competition Act). ${ }^{62}$ To convince someone means to influence his decision by persuasive methods and not necessarily against someone's will ${ }^{63}$ or to do something bad or illegal. ${ }^{64}$ Coercing (standard used by the ECN+ Directive) involves use of force or threats, ${ }^{65}$ obtaining a decision against someone's will and therefore is an action characterised by greater degree of malice. The Polish term is more difficult to apply ${ }^{66}$ and forecloses a broader (in comparison to the ECN+ Directive) group of potential applicants from the possibility to apply for immunity ${ }^{67}$ (critically: Turno, 2013, p. 511; Molski, 2014, p. 1418; Piszcz, 2015, p. 50; Korycińska-Rządca, 2018, p. 71). Amending this provision

${ }^{61}$ See Article 113b(2)(b) of the 2007 Competition Act and Article 17(c)(ii) of the $\mathrm{ECN}+$ Directive.

62 Polish: naktaniat, in other words persuading or convincing.

63 See PWN dictionary: https://sjp.pwn.pl/slowniki/nak\%C5\%82ania\%C4\%87.html (30.06.2019).

64 Therefore the English term 'instigate' (https://www.lexico.com/en/definition/instigate (30.06.2019)) or 'incite' (https://www.lexico.com/en/definition/incite (30.06.2019)) would not be the best equivalent to Polish 'naktaniac'.

65 See Oxford: https://www.oxfordlearnersdictionaries.com/definition/english/coerce\# coerce_inflg_2 (30.06.2019) and Lexico dictionary https://www.lexico.com/en/definition/coerce (30.06.2019).

${ }^{66}$ It is not always clear when certain behaviour attains the level of a persuasion, e.g. will repeated invitation from a market leader combined with his participation in an infringement or just a passive behaviour qualify as such? The term was not clarified in the 2017 Polish Guidelines.

67 Although it may just result from the fact that the Polish language version of the 2006 Leniency Notice in para. 13 uses the same term ('naktaniać'). Interestingly, the English language version of the 2007 Competition Act available at the Polish NCA's web-site uses the English 
is not required (because the ring-leader exception is provided in Article 17(3) and not in Article 17(2), see comments in Section 2.1. above $)^{68}$ but it may contribute to enhancing efficiency of the PLP.

\subsubsection{Priority requirement: first to submit relevant evidence or first to fulfil all conditions}

Sixthly, a fresh look concerning the 'priority' requirement is needed. According to the PLP, an applicant in order to qualify for immunity has to, as the first, meet cumulatively the following conditions:

(i) submit the required application covering detailed description of an infringement,

(ii) not disclose his intention to apply for immunity,

(iii) fully cooperate with the Polish NCA starting from the moment it applied for immunity,

(iv) cease participation in the reported infringement and

(v) provide the relevant evidence (or information, as defined above) (Article 113b(1)-(2) of the 2007 Competition Act).

The scope of duties (i)-(iv) is comparable to the general conditions for leniency set out in Article 19 of the ECN+ Directive. Contrary to the PLP, the ECN + Directive does not extend the 'priority' requirement to those obligations. It is sufficient that the applicant is first to submit the relevant evidence (as discussed above, see Article 17(2)c).

This is a more reasonable method. Determining who was the first to satisfy requirements that relate in many cases to continuous actions extended over a long period of time is impossible. Therefore, in the interest of transparency and clarity, the PLP terms should be reformulated to reflect the approach taken in the ECN+ Directive.

\subsubsection{Duty to confirm the granting of conditional immunity}

Lastly, the ECN + Directive provides that the NCA must inform the applicant of whether or not it has been granted conditional immunity from fines (on the applicant's request information is in writing, Article 17(4)). No time-limits have been specified in that regard.

According to the PLP, the Polish NCA confirms this information immediately (after it has reached the relevant conclusion) in writing and

term 'coerce' and the Polish language version of the ECN+ Directive in Article 17(3) uses incorrectly the word 'naktaniać'.

68 There are arguments justifying view that the entire of Article 17, 18 and 19 are subject to maximum harmonisation. Król-Bogomilska, 2018, p. 20 pointed that such change is required in view of the earlier draft of the ECN+ Directive. 
without the applicant's request. ${ }^{69}$ Clearly, the PLP provides for better and broader information standards (confirmation relates also to the application for a reduction of fines). In this area, requirements for maximum harmonisation do not apply, hence the relevant provisions do not need amendments.

\subsection{Specific conditions for a reduction of fines}

\subsubsection{Relevant evidence}

The specific conditions for a reduction of fines in the ECN+ Directive are limited to the obligation to provide relevant evidence. In this case the evidence meets the threshold of relevance if it represents significant added value for the purposes of proving an infringement and is relative to the evidence that the NCA possessed at the time of the application (Article 18(2)c).

The PLP requirement in this respect is comparable. The applicant must provide an evidence that is of substantial importance for the proceedings and was not in the Polish NCA's possession. ${ }^{70}$ It can be inferred from this wording that it concerns evidence that was new at the time of the application. ${ }^{71} \mathrm{In}$ practical terms, the meaning of this requirement is the same as the meaning of its equivalent in the ECN+ Directive. ${ }^{72}$ Additionally, the Polish NCA clarified that this is an evidence that strengthens by its nature and level of detail its ability to prove an infringement (which mirrors the approach in the MLP) and 'proves certain facts and increase the level of detail of information already in the Polish NCA's possession'. ${ }^{73}$

Bearing the above in mind, and the non-binding nature of the 2017 Polish Guidelines, it would be in the interest of transparency and certainty to adjust the wording of the PLP's relevant provisions to the ECN+ Directive.

\subsubsection{Lack of rules on fine reduction}

The ECN + Directive does not specify the manner in which a fine should be reduced or relevant redaction criteria. Nor does it determine the impact

69 See para. 6(1) and 7 of the 2014 Procedural Regulation. Additionally, the Polish NCA confirms the date and the time of submitting a leniency application (Article 113a(4) of the 2007 Competition Act).

${ }^{70}$ See Article 113c(1)3 of the 2007 Competition Act. Contrary to the rules applicable in case of an application for immunity, only one threshold for relevant evidence was foreseen with respect to applications for a reduction of fines and it excludes the concept of the relevant information.

${ }^{71}$ This is not explicitly confirmed in the relevant para. 14, 17 and 18 of the 2017 Polish Guidelines as it refers to a general expression 'new and unknown earlier'.

72 Infra and Turno, 2016, p. 1522-1523.

73 See para. 18 and 14 of the 2017 Polish Guidelines and para. 10 of the MPL. 
that the rejection of an application or disqualification from benefits at the end of the proceedings has on the place in the queue of others. ${ }^{74}$

The manner in which the reduction is calculated according to the PLP follows the system introduced in paragraph 26 of the 2006 Commission Leniency Notice. ${ }^{75}$ The PLP also provides that rejected applications will be disregarded when determining the eventual order in a queue, but applications withdrawn or disqualified after a conditional leniency was granted will not impact the original order. ${ }^{76}$ These provisions will not require amendments in the implementation process.

\subsubsection{Partial immunity}

The ECN+ Directive foresees partial immunity. ${ }^{77}$ Accordingly, if an applicant submits compelling evidence that enables the NCA to prove additional facts allowing to increase the level of fines, this evidence should be disregarded when setting the fine imposed on that applicant. In other words, only the fines of other infringers can be enlarged based on this aggravating circumstance.

This rule will have to be introduced into the PLP, because the general rules on the setting of fines will not be sufficient to ensure such guarantee (Turno, 2016, p. 1525; Król-Bogomilska, 2018, p. 20; Materna, 2018, p. 44).

\subsubsection{Simultaneous applications for immunity and a reduction of fine}

There are two specific characteristics of the PLP concerning a reduction of fines that need considering from the perspective of the ECN+ Directive, namely the possibility to make simultaneous applications and the institution referred to as 'leniency plus'.

According to the PLP, an applicant may simultaneously file an application for immunity and for a fine reduction (the Polish NCA considers the latter, should the applicant fail to qualify for immunity).

The MLP (paragraph 20), which the ECN+ Directive is based on, provides that the undertaking may request the NCA to consider its application for

74 This is one of harmonisation deficiencies, see comments in Section VI.

75 See Molski, 2014, p. 1423; Skoczny, 2016, p. 171; Korycinska-Rządca, 2018, p. 72, who described in detail the PLP applicable rules, i.e. Article 113c (2) of the 2007 Competition Act. See also Kulesza, 2015, p. 86-87, 97 concerning historical versions of this provision.

76 Para. 8 and 11 of the 2014 Procedural Regulation.

77 See Article 18(3) of the ECN+ Directive that is comparable to the solution provided for in the 2006 Commission Leniency Notice (para. 26 in fine) and the MLP (para. 12 and para. 26 of the explanatory notes). 
a reduction of fine after its application for immunity was rejected (unless from the outset it applies only for a reduction of fines, for example because it coerced others to participate in an infringement).

Article 17(4) of the ECN+ Directive contains a similar statement: the applicant may request a reduction of fines in case the NCA reject its application for immunity. The language is not conclusive as to whether the applicant may upfront request immunity and, alternatively (in case of rejection), a reduction of fines. Therefore, the PLP's current approach to alternative requests may remain unchanged.

\subsubsection{Leniency Plus}

The other particularity of the PLP is that since the 2014 Amendment it provides for a solution referred to as 'Leniency Plus'. This provision allows the undertaking that applies for a reduction of fines in relation to one infringement ('first infringement') to receive an additional $30 \%$ reduction of fines to be imposed for the first infringement, if it is the first to report another, unknown ${ }^{78}$ infringement ('second infringement'). The applicant must submit evidence enabling the Polish NCA to launch a full-fledged investigation with respect to this other (second) infringement (that is, relevant evidence fulfilling the regular 'threshold one' requirement that would be applicable if the applicant would merely request immunity in relation to the second infringement). The Leniency Plus option is foreign to the MLP and the EU systems (Piszcz, 2016, p. 215) although it is applied in several Member States (examples in Skoczny, 2015, p. 171 and Martyniszyn, 2015, p. 13).

Initially it was considered that in light of the ECN + Directive' drafts, amendments to Polish Leniency Plus would not be necessary (Materna, 2018, p. 44). The final wording of the ECN + Directive provides, however, strict requirements for fine reductions (Article 18(2)) which the Member States should not depart from (see considerations in Section V.2.1. above). In particular, the ECN+ Directive allows for reduction of fines if an applicant

78 I.e., an infringement that is not subject of any (preliminary of full-fledged) Polish NCA proceedings. Apart from this additional fine reduction, the undertaking may benefit from leniency (presuming also reduction of fines) with respect of this other infringement, provided it complies with all applicable leniency conditions. See Article 113d of the 2007 Competition Act. The institution is subject of hefty criticism. Apart from many general legislative flaws, it has systemic deficiencies, e.g. because it is optional for the applicants and introduced a very high and rigid uplift (30\% instead of a rage of reduction) applicable multiple times and regardless of the significance of the other revealed infringement (Martyniszyn, 2015, p. 13-14; Skoczny, 2015, p. 172). Additionally, the PLP provides no guidelines on how to differentiate the agreements or calculate fine reductions (Semeniuk and Syp, 2013, p. 33-41; Piszcz, 2015, p. 52; Piszcz, 2016, p. 216). 
discloses its participation in a cartel and provides an evidence of the alleged cartel which represents significant added value for the purposes of proving an infringement covered by the leniency programme, relative to the evidence already in the NCA's possession (Article 18(2)(c)). It stems from the above wording that the reduction of fines is granted in exchange of evidence that must relate to the initially reported cartel (the cartel under investigation) and not to any infringement. Leniency Plus is an option for discount uplift by definition based on evidence unrelated to the alleged cartel (evidence concerning a 'second infringement'). Hence, if a maximum harmonisation approach is endorsed, the scope of Polish Leniency Plus will necessitate amendments. Normally it could not justify additional leniency-based reduction of fines imposed for participation in cartels (were the Member States should not modify the rules provided in the ECN+ Directive). It could, nonetheless, continue to apply in relation to other, non-cartel infringements (where by force of Article 18(1) of the ECN+ Directive, the Member States retained more flexibility in determining criteria for fine reductions).

The ECN+ Directive does not imply a modification of the rules on which leniency is granted with respect to the additionally reported infringement (the 'second infringement'), otherwise than discussed in the preceding sections.

\subsection{General leniency conditions}

Pursuant to the ECN+ Directive, ${ }^{79}$ a leniency applicant in order to qualify for immunity or a reduction of fines must fulfil a set of general conditions. Those apply in addition to specific conditions, and cover the duty to:

(a) disclose to an NCA its involvement in a secret cartel and end participation in it, at the latest immediately following its leniency application, except in cases where (in view of the relevant NCA) continued involvement is reasonably necessary to preserve the integrity of the investigation, ${ }^{80}$

(b) cooperate genuinely, fully, on a continuous basis and expeditiously with the NCA during the entire enforcement proceedings, ${ }^{81}$ including:

(i) providing promptly all relevant information and evidence (in the applicant's possession or accessible to it), in particular: (i.1.) applicant's name and address, (i.2.) names of all past and current

79 Articles 17(2)a-b, 18(2)a-b and 19.

${ }^{80}$ Meaning in particular that the delay in ending such participation is necessary to prevent the discovery of the cooperation by other cartelists.

81 Duty of cooperation lasts until the closure of the NCA's enforcement proceedings against all parties under investigation (by adopting the decision or otherwise), see Article 19(b) of the $\mathrm{ECN}+$ Directive. This means that it does not extend to the judicial review phase, if such is provided under applicable law, as it is the case in Poland. 
cartel participants, (i.3) detailed cartel description (including the nature of the conduct, the duration and the affected products and the territories) and (i.4) information on any leniency applications (past or future) in relation to the same conduct;

(ii) remaining at the NCA's disposal to answer any request that may contribute to the establishment of facts;

(iii) making staff available for interviews (directors, managers and other members), including making reasonable efforts to ensure availability of former staff;

(iv) not destroying, falsifying or concealing evidence (including in the period when the applicant contemplates submitting the application);

(v) not disclosing the fact of cooperation with a NCA or any content of application (except to another competition authority) ${ }^{82}$ starting from the time the applicant contemplates an application until the NCA issues the objections (unless otherwise agreed).

In principle, the PLP (Article 113a of the 2007 Competition Act) corresponds to the requirements of the ECN+ Directive. There are minor differences that should be addressed taking into account the pertinent standard of harmonisation. ${ }^{83}$

Following the 2014 Amendment, the applicant is required to cease its participation in an infringement immediately after submitting the application (previously it was the day when it submitted the application). This provision corresponds on substance to the ECN + Directive, although the latter grants the NCA an option to set the exit date. The Polish NCA should be vested in similar powers.

In the PLP, no end-date was set for the duty to cooperate fully with the NCA (for example, it is not clear whether it covers a judicial review phase), continuous and genuine character of cooperation is assumed. Those issues should be addressed..$^{84}$

82 An applicant may report its behaviour also to other public authorities as required by law, provided it does not disclose the fact that it contemplates filing for leniency, hand over the leniency statement and considers the importance of not adversely impacting the NCA's potential investigation (Recital 56 of the ECN+ Directive).

83 Detailed discussion of each of the requirements in the light of the PLP's current standards exceeds the scope of this publication, therefore only main differences are addressed briefly in this Section.

84 Unfortunately, the ECN+ Directive does not clarify how to assess situations when applicants file for leniency but attempt at the same time to paralyze the NCA's investigation by multiple recurse to judicial review relating to incidental issues (before final decision is issued), for instance by filing appeals concerning protection of business secrets or inspector's actions during the dawn raid. 
Under the PLP, the applicant must provide all relevant information and evidence as expected pursuant to the ECN+ Directive, either because it is mandatory content of the application or it is a part of the duty to cooperate. The PLP's provides more details on what the description of the infringement normally includes (the objective and circumstances in which the agreement was concluded, each participant's and key individuals' role). Additionally, in Poland, the duty to provide evidence covers now only evidence of significant relevance for the matter (the ECN+ Directive requires all relevant evidence). In practical terms the latter difference is nil.

The scope of information currently required in Poland regarding other leniency applications should be extended. It should include also future and non-EU applications.

In relation to staff interviews, under the PLP, the applicant has a negative duty (not to obstruct). It should have a positive duty to make staff available, including former staff (reasonable efforts).

Duty not to destroy, falsify or conceal evidence should be changed to include the period when the applicant contemplates submitting an application. A clear-cut time frame applicable by default to the duty not to disclose the fact that an application was submitted (and implicitly the content of it) should be introduced. Nowadays, the consent of the Polish NCA is always required in that regard. ${ }^{85}$

There is no explicit duty under the PLP to remain at the Polish NCA's disposal to answer any requests, this can be however inferred from the remaining obligations. It should be added out of concern for clarity and transparency.

\subsection{Duty to grant leniency}

Pursuant to the relevant provisions of the PLP, the Polish NCA is under an obligation to grant immunity from or a reduction of fines if an applicant meets the relevant conditions. Nonetheless, the Polish NCA decides whether the conditions are fulfilled. Hence in practice, the Polish NCA enjoys quite a discretion when granting leniency benefit. ${ }^{86}$

This issue has not been addressed in the ECN+ Directive, ${ }^{87}$ therefore the PLP does not require amendments in this respect.

85 See Article 113a(5) item 4 of the 2007 Competition Act Piszcz, 2015, p. 50, following the 2014 Amendment suggested that an explicit waiver allowing disclosure to advisors and other competition authorities should be added.

86 Turno, 2016, p. 1514. The situation is similar in case of a reduction of fines, it stems from the wording of Article 113b and 113c of the 2007 Competition Act.

87 See Section VI for critical comments. 


\section{Form of leniency statements and confirmations}

The ECN+ Directive in Article 20 and 21(4) lays down minimum requirements as to the application's form and language as well as obligatory confirmations. Pursuant to those provisions, leniency statements in full and summary applications may be submitted in writing, orally or in any other form not permitting the applicants to take control of such statements. The statements as well as markers can be submitted in the language of the given ECN or one of agreed Union languages. No language that could be used universally was selected upfront ${ }^{88}$

The PLP meets the majority of these standards (paragraphs 2-3 of the 2014 Procedural Regulation). In Poland, the leniency statement along with relevant evidence may be submitted in writing or orally ${ }^{89}$, in person, by post, fax or e-mail. In case of a faxed application, or a digital application not encrypted with a secured electronic signature, the statement and the attached evidence must be certified ${ }^{90}$ (on the fifth working day following the e-submission at the latest) in order to preserve the timing of the original (digital or by fax) submission.

The form in which a summary application (or a marker) can be submitted is not expressly specified in the 2014 Procedural Regulation, it can be only inferred from its paragraph 3(4) that summary application can be submitted in writing or orally. This is an example of a situation, where it is assumed that some provisions of the 2014 Procedural Regulation referring to the general term 'application' (in this context general provisions regulating the form of the application, discussed above) apply to any application (full, summary or a marker). In fact, the 2014 Procedural Regulation often relies on a general term 'application' without specifying what kind of application it is, nor defining that term. ${ }^{91}$ Only in some places it clearly differentiates between

88 This is one of harmonisation deficiencies, see comments in Section VI.

89 In this case, the Polish NCA retains sound recordings and records in a written protocol the exact timing when the submission started and ended ; the time when the applicant presents himself at the office (as evidenced in entry/exit records) is considered to be the submission time (para. 2 (5-6) of the 2014 Procedural Regulation). Paras. 62 to 65 of the 2017 Polish Guidelines provide additional clarifications. (i) The applicant may sign the written protocol (along with the Polish NCA's representative. (ii) Attached evidence should be in a carbon copy. (iii) Transcripts of oral statement are included in the case file and shared with the parties prior to the issuance of the decision (according to Article 70 of the 2007 Competition Act). (iv) Only the Polish NCA's representative sings the transcripts. The author submits that the parties should have access not only to the transcripts but also to the original recording.

90 I.e. an applicant must submit a carbon copy with a signature (of an authorised employee or of a qualified lawyer, tax advisor, patent officer or government agent) certifying that it is a true and exact copy of an original (Article 51 of the 2014 Competition Act).

91 Article 113a of the 2007 Competition Act sort of defines the term 'application' and Article $113 \mathrm{e}$ and $113 \mathrm{f}$ only refer to marker and summary applications, respectively. Those terms 
an 'application' and a 'summary application'. In most instances the former provisions are of such nature that it is fully justifiable to conclude that they apply to any application. However, this is not always the case..$^{92}$

This is a legislative flaw that should be corrected, including in the context of the form of an application. It should be clearly stated when specific provisions apply not only to a full application but also to a summary application and a marker. Additionally, those terms should be properly defined. This, in particular, concerns the provisions regulating the manner in which the application may be filed, its form, the way it is recorded etc (paragraph 2 of the 2014 Procedural Regulation) or to the duty to return rejected or withdrawn applications (Article 113g of the 2007 Competition Act).

Only summary application can be submitted in English, if its Polish language version is provided within thirty days following the original submission. ${ }^{93}$ The implementation of the ECN + Directive requires allowing the Polish NCA to accept all leniency statements and markers (but not necessarily the accompanying evidence) in Polish or other, mutually agreed language version. Accounting for this option necessitates an amendment of Article 51(2-3) of the 2007 Competition Act, according to which all evidence before the Polish NCA must be in or translated into Polish (certified translation), unless the leniency statement is considered as pleadings and not an evidence.

The Polish NCA ex officio (i) confirms (in an unspecified form) the date and time of the receipt of a full leniency statement (a summary application or marker are not expressly mentioned in this context, but see comments above), (ii) in case of a summary application, confirms in writing whether it was or not the first application and informs (in an unspecified form) other applicants (it is not specified if it includes summary applicants or applicants

should be properly defined in Article 4 of the 2007 Competition Act that contains systemic legal definitions.

92 E.g. para. 6 or 5 of the 2014 Procedural Regulation (imperative requiring the Polish NCA to immediately request the applicant to mend incomplete applications) clearly should not apply to summary applications.

93 The Polish language version of the statement may be submitted in an oral form. In that case, the Polish NCA proceeds as specified in footnote 90 above (para. 3(4) of the 2014 Procedural Regulation). Importantly, the 2017 Polish Guidelines (not binding document) refer to a translation of the statement (clarifying that it does not have to be a certified one) and not to a 'Polish language version' of the statement. It also states that the translation must be signed and that it is the governing version of the application (para. 67 of the 2017 Polish Guidelines). That tiny detail makes a considerable difference. The applicants are unwilling to sign the statements or the translations (due to concerns related to private enforcement). The Polish language version of the application should be treated as an application and not the translation of it. Therefore it can be submitted in an oral form (as specified above) without an obligation to sign it (the applicant may sign the minutes merely stating the beginning and the end of the submission time). 
requesting marker, but see comments above) that a first summary application was already submitted, (iii) confirms in writing the leniency applicant's conditional place in a queue or (iv) informs immediately in writing that the applicant has not qualified for leniency and explains the reasons behind such conclusion. Additionally, the Polish NCA may give the applicant (including applicant requesting a marker) a reasoned warning in writing that it may fail to meet the leniency requirements to allow the applicant to mend the situation. ${ }^{94}$ Article 20(2) of the ECN+ Directive specifically requires that receipt of a full or a summary application and the date and time of such receipt is confirmed in writing (at least when requested). Therefore, the implementation will require adjustments regarding the written form and express reference to a summary application in relation to confirmation listed in point (i) above. ${ }^{95}$ However, specifying in all cases when the particular provision relates also to summary applications and markers and sorting the issue of legal definitions, is strongly recommended for the reasons set out earlier in this Section.

\section{Marker}

A marker must be differentiated from summary applications (discussed in Section V.5 below). In brief words, a marker is a preliminary application in a shortened form filed by the undertaking that for different reasons, usually time constraints, was unable to prepare at the outset a full application. If completed, a marker allows to reserve a place in a 'domestic' leniency queue. Summary applications (discussed in more details in the next section), can be filed before the NCAs only by undertakings applying for leniency with the Commission, in order to reserve a place in a 'domestic' leniency queue should the Commission refrain from pursuing the case. It is a 'provisional' application that releases the undertakings from a need of filing a full leniency application to a given NCA simultaneously with the application to the Commission.

The ECN+ Directive (Article 21) requires that the Member States accept leniency markers that enable the applicant to reserve a place in the queue for immunity and (optionally) a reduction of fines before the NCAs. It also sets out the minimum content of a marker, however the information listed in there should be provided if it is available to the applicant. Provisions relating to

94 Such reasoned warning should be given only after the Polish NCA confirmed the applicant's conditional place in the queue, earlier warnings appear premature and overly burdensome for the authority. Article 113a(4) of the 2007 Competition Act and para. 3 (1-2), 6, 7 and 9 of the 2014 Procedural Regulation. See also comments in V.2.2.6. above.

95 I.e. in relation to Article 113a(4) of the 2007 Competition Act or para 3(1) of the 2014 Procedural Regulation. 
markers are considered to be based on a minimum harmonisation approach (Aresnidou, Infra).

The PLP (Article 113e of the 2007 Competition Act) provides for possibility to submit a marker to reserve a place in the queue for immunity and in the queue for a reduction of fines (this can be done simultaneously, that is, in one marker at the outset of the proceedings) and with respect to all Article 101 infringements. This is provided that the applicant perfects the application within time-limits ${ }^{96}$ discretionally specified on a case-by-case basis and that complete information is not at the applicant's disposal ${ }^{97}$ at the time of a marker submission. The PLP sets slightly different requirements concerning the minimum content than the ECN+ Directive. The description of infringement should include information on key individuals and their role. Conversely, information on other leniency submissions and the bases for the concern behind the request is not required. More importantly, all of the minimum information must be provided (not only if it is available) in order to successfully request a marker. ${ }^{98}$ However, if this condition is met and the undertaking perfects its application, the place in the queue is automatically reserved (Turno, 2016, p. 1534; Korycinska-Rządca, 2018, p. 73-75).

This approach will have to be changed to satisfy the ECN + Directive explicit requirement to invest the NCAs with the discretion whether to grant a marker or not. ${ }^{99}$ Uncertainty in this regard incentivises the applicants to submit full applications in a first place and markers only as a last resort. Otherwise the marker benefit may be abused (Korycinska-Rządca, 2018, p. 74,

96 The Polish NCA may extend those deadlines (Turno, 2016, p. 1535-1536; Modzelewska-Wąchal, 2014, p. 1433). Turno recommends setting at least tentative time limits; the recently published indications (14 to 35 days) in para. 22 of the 2017 Polish Guidelines seems to be sufficient in that regard. The Polish NCA determines the time limits and scope of missing information without delay. This approach is favourable for potential applicants, but burdensome for the authority (in particular that nowadays, in majority of cases the applicants request markers). The scope of evidence and information required for leniency has been defined elsewhere, therefore the Polish NCA should not be additionally obliged to list it for applicants requesting the marker.

97 The 2017 Polish Guidelines refer to information that is not in the applicant's 'possession', it should be understood as information that is not at the undertakings immediate disposal, e.g. because the raw data it possesses (e-mail backup) needs processing.

98 The applicant may 'submit an application in a shortened form containing the description of the infringement that at least convers [...\} (Article 113e of the 2007 Competition Act, emphasises added). Modzelewska-Wąchal, 2014, p. 1432.

99 In this case, a rigid condition to provide all of the minimum content could be relaxed, as the authority would have the ability to reflect on whether the application is nonetheless well substantiated and the deficiencies are justified (note, there is no formal requirement to justify the request for a marker) and possibly balanced with other information. (Turno, 2016, p. 1535 emphasises that the applicant can always resubmit the marker or full application). 
same approach is taken in the MLP and 2006 Commission Leniency Notice). ${ }^{100}$ There is no requirement to remove from the PLP the possibility to make simultaneous marker requests for immunity and for a reduction of fines. Such change is nonetheless recommended as it would further motivate the infringers to come forward sooner (infra). Turno, 2016, p. 1534 suggest that the possibility to apply for a marker in relation to a reduction of fines should be removed altogether. Retaining the marker option with respect to non-cartel infringements does not run counter to the ECN+ Directive either. However, comments expressed in Section V.2.1. above apply accordingly. Additionally, in the implementation process, the minimum content list should be expanded to cover the two missing items mentioned above, without however a need to delete the requirement for information relating to key individuals.

Unfortunately, the ECN + Directive does not provide any guidelines when, at the latest, the applicant submitting a marker should cease the infringement. The NCA should have discretion to set relevant time limits as in the case of full applications (Article 19(a) of the ECN+ Directive). A rigid requirement to end an infringement at the latest immediately following the submission of a marker (considered in the literature) may adversely impact the ability to perfect the marker or the integrity of the investigation (to some extent differently: Turno, 2016, p. 1537).

\section{Summary application}

The ECN+ Directive failed to introduce a one-stop-shop system and continues to relay on summary applications. ${ }^{101}$ This measure allows an undertaking applying before the Commission for either immunity or a reduction of fines (in relation to cartel affecting at least three Member States) to take steps to reserve a place in a queue before the NCAs (in relation to the same infringement) by filing a simplified application. The latter is, in brief, a summary of the application submitted to the Commission. The applicant may be granted a place in a 'national' queue, should the Commission refrain from pursuing the case in whole or in part (and provided other conditions are met). The provisions relating to this subject (Article 22 of the ECN + Directive) are more demanding and pursue maximum harmonisation approach. Hence, the Member States are left with little flexibility when implementing them.

The ECN + Directive sets out the minimum content of a summary application (Article 22(2)). Those requirements are similar to those applicable with respect

100 Król-Bogomilska, 2012, p. 10, points, however, that some commentators perceive such uncertainty as a negative (dissuasive) factor.

101 This is one of harmonisation deficiencies, see comments in Section VI. 
to markers and cover the description of the infringement (parties, nature, geographical and product scope, duration), other past and future applications and the list of Member States where the evidence is likely to be located.

In order to fully correspond to those conditions, Article 113f(3) of the 2007 Competition Act (that sets out the rules applicable to summary applications) will have to be amended to require (as a part of minimum content) information concerning past or future leniency applications made in non-EU countries. Secondly, the PLP will need to recognize expressly the possibility to file a summary application when the undertaking applies before the Commission for a reduction of fines (now this solution is available only to the immunity applicants, Modzelewska-Wąchal, 2014, p. 1435; Korycińska-Rządca, 2018, p. 75) $)^{102}$ or submitted to the Commission a marker and is in the process of perfecting it. Previously the latter option was only assumed (Turno, 2016, p. 1539; Korycińska-Rządca, infra). Currently, and in line with the $\mathrm{ECN}+$ Directive (Article 22(2)), in the PLP all of the minimum content requirements must be met in order for the applicant to avail the benefits of a summary application. ${ }^{103}$ The PLP allows summary applicants to reserve a place in a 'domestic' queue for both: immunity and a reduction of fines (Infra) and only with respect to cartels, excluding applications from individuals because such broader applications before the Commission are not possible. ${ }^{104}$ As a consequence, parties to non-cartel infringements or individuals may not apply for leniency before the Commission and must thus submit a full application or a marker before the Polish NCA, if they wish to benefit from leniency in Poland.

The current practice of the Polish NCA's corresponds to the majority of the ECN + Directive process provisions relating to handling of summary applications. ${ }^{105}$ The following rules will, however, have to be transposed into binding law:

a) the Commission shall be the main interlocutor of the applicant until it decides to refrain from pursuing the case (and informs accordingly the relevant NCAs) ${ }^{106}$;

102 Article 22(1) of the ECN+ Directive mentions leniency applicants, while Article 113f(1) of the 2007 Competition Act refers to immunity applications only.

103 Article $113 \mathrm{f}(2)$ of the 2007 Competition Act uses imperative language regarding the content of summary applications: an application 'shall consist of', 'includes'; Modzelewska-Wąchal, 2014, p. 1435 expressed the concurrent opinion.

104 The EU law does not provide grounds for imposing sanctions on individuals (not having a status of undertakings) for competition-related infringements with one exception only discussed by Król-Bogomilska, 2010, p. 5.

105 See $24-32$ of the 2017 Polish Guidelines.

106 For instance, in such matters as deciding on when exactly the applicant should cease its participation in a cartel. 
b) during this period the Polish NCA may request specific clarifications only in the areas covered by the minimum content and ask for a full application only exceptionally (when strictly necessary for case delineation or case allocation, Article 22(5) of the ECN + Directive);

c) submitting the evidence or full application during this period is optional (currently it is required after the Polish NCA decides to open the investigation, but the earliest point in time when the latter can happen is not specified ${ }^{107}$ );

d) the full application is considered to be submitted at the time of submitting the summary application (provided it is timely completed) only if the time, product and geographical scope of the original or updated summary application was in line with the application to the Commission (Article 22(6) of the ECN + Directive); the latter condition is not reflected in Article 113f(5) of the 2007 Competition Act and paragraph 31 of the 2017 Polish Guidelines only mentions that the applicant may update the summary application;

e) the Polish NCA already has a duty to inform the applicant if he is the first participant to report the cartel before the Polish NCA in the form of a summary application (paragraph 3 of the 2014 Procedural Regulation); this obligation should be broadened to account also for undertakings that came clear in a form of a full application. ${ }^{108}$

To the satisfaction of the ECN+ Directive's standards (Article 22(5)), the Polish NCA has the discretion to set the time limits for completing a full application (Article 113f(4) of the 2007 Competition Act). Providing tentative time-limits in this regard in the 2017 Polish Guidelines would be helpful.

\section{Individual sanctions}

The ECN+ Directive (Article 23(1) requires that the staff of an infringer, including the directors and the managers, is protected from individual sanctions (such as fines or disqualification). The requirement concerns sanctions that can be imposed in administrative and non-criminal judicial

107 See Article 113f(4) of the 2007 Competition Act. There is no express obligation of the Polish NCA to open a formal proceeding following the receipt of a leniency application (Turno, 2016, p. 1499) and even more so following the receipt of a summary application or a marker (Modzelewska-Wąchal, 2014, p. 1431, 1435).

108 See Article 22(4) of the ECN+ Directive. Informing a summary applicant about the markers from other parties is not required, however it can be assumed that in such case the NCAs may wait until the time for perfecting the marker lapses and then eventually inform about full applications. 
proceedings ${ }^{109}$ in relation to those individuals personally involvement in a cartel (covered by the application for immunity). Immunity from individual sanctions should be granted provided that (i) the infringer (an undertaking) reported the cartel and was the first to provide relevant evidence meeting the thresholds for immunity (that is, fulfils conditions set out in Article 17(2)(b)-(c)), (ii) the concerned individual cooperated actively with the NCA pursuing the case and (iii) the application for corporate immunity (i.e. the undertaking's application) was made before this individual was made aware by the NCA about the proceedings against him or her (that is, the proceedings that could lead to the imposition of individual sanctions).

Under the same conditions, immunity from criminal liability (sanctions imposed in criminal proceedings such as imprisonment) should be ensured if the individual concerned also cooperates with the prosecuting authority. Alternatively, immunity or a mitigation of such sanctions should be ensured if, in addition to the conditions specified above, the contribution of such individual to detecting and investigating the cartel outweighs the interest in prosecuting and/or sanctioning of such individual (Article 23(2)-(3), see critical comments in Section VI below).

The NCA pursuing the investigation and a foreign prosecuting authority should communicate via the NCA where the proceedings that may lead to the imposition of individual sanctions take place. These rules do not impact the right to claim damages foreseen in the Damages Directive (Article 23(4)-(5) of the ECN+ Directive).

In Poland, following the 2014 Amendment, staff having managerial functions ${ }^{110}$ may be held accountable by the Polish NCA for knowingly allowing an infringement of Article 101 and its national equivalents (except for bid-rigging) to take place (this is conditioned upon establishing the undertaking's liability). ${ }^{111}$ Leniency options have been introduced at the

109 For violations of national law that pursue predominantly the same objective as Article 101 TFEU, e.g. prohibition of bid-rigging (see Recital 64 of the ECN+ Directive).

110 Defined in Article 4 (3a) of the 2007 Competition Act as: individuals managing the undertaking, including members of managing bodies or staff with managerial functions. For an extensive analysis of the term see Piszcz, 2013, p. 25-26 (who suggested that this includes any person managing the company's business (as a whole)) and Król-Bogomilska, 2015, p. 8-9 (who for instance pointed out that it cannot be entirely excluded that even a person de facto managing the company's affairs is subject to such liability).The broad spectrum of possible interpretation only demonstrates that this provision is far from being perfect. This is inadmissible situation in view of the fact that this is law setting grounds for quasi-criminal liability and the Polish NCA's growing appetite to apply it.

111 Article 6a, 113h-113j of the 2007 Competition Act. Bernatt and Turno, 2015, p. 88-92 severely criticised this aspect of the 2014 Amendment, because it introduced in fact quasi-criminal liability of individuals without ensuring proper procedural guarantees that meet the standards 
same time (that is, the possibility of submitting a leniency application by the individual, or alternatively automatically extending to such individuals the benefits of corporate applications, in cases when the company submits leniency application before such individual). ${ }^{112}$ The latter decision was a welcome development although still requiring some improvements. ${ }^{113}$

Protection of individuals availed by the PLP is broader comparing to the $\mathrm{ECN}+$ Directive because it also covers staff of an infringer that applies for a reduction of fines (therefore not only the staff of an immunity applicant) and additionally applies in relation to non-cartel matters. In this area the minimum harmonisation approach was taken in the ECN+ Directive. Hence there is no need to narrow down the scope of the protection stemming from the PLP, with one exception. Namely, immunity from individual, cartel-related sanctions should not be available where the immunity application (corporate or individual) was submitted after the Polish NCA instituted a full-fledged proceedings against the given undertaking and the individual concerned and informed (made aware) the later about that fact (a reservation originating from condition (iii) listed above). A requirement to this end must be implemented in Poland.

The Polish legal system criminalises bid-rigging of public tenders (Article 305 of the Polish Penal Code) ${ }^{114}$ without, however, any system of leniency-related immunity or fine reductions. ${ }^{115}$ In this respect Poland will have to implement new solutions (Materna, 2018, p. 44). That is, the law should provide at least for the possibility to take the immunity application and cooperation of the accused individual into account as a factor alleviating the final penalty or circumstance excluding liability altogether (institution comparable to Article 229 paragraph 6 of Polish Penal Code providing for active repentance in corruption matters).

of criminal procedure. Król-Bogomilska, 2015, p. 8-10, also pointed to significant legislative flaws in this respect, mainly related to penal nature of this liability.

112 Option discussed in detail by Król-Bogomilska, 2015, p. 11.

113 For instance, it is unclear if there is only one leniency queue (for undertakings and individuals), critically Piszcz, 2015, p. 50; in favour Turno, 2016, p. 1545; what should be the status of an individual after the company withdraws its application altogether (should he consider filing his own application?), etc.

114 Rumak, Sitarek, 2009, p. 101 point in addition to Article 286 of the Polish Penal Code (fraud) that might be relied upon to impose criminal sanctions for rigging private tenders. This option runs, however, the risk of violating the principle nullum crimen sine lege stricta. Discussing this problem in detail exceeds the subject of this publication. Compare also Molski, 2014, p. 1408, referring in addition to Article 296 of Polish Penal Code (abuse of trust).

115 This is perceived as one of the reasons behind the low effectiveness of the PLP (Rumak, Sitarek, 2009, p. 101). 


\section{Protection of leniency information}

The ECN+ Directive (Article 31 and recital 72) limits access to corporate statements and the use of leniency information (these rules apply to cartel-related leniency only). It provides that exclusively the parties to the proceedings may be granted access to corporate leniency statements (and settlement submissions) with the sole purpose of exercising their right of defence. In judicial proceedings, the parties may use information from leniency statements obtained through access to the NCA's file only (i) before the court reviewing the NCA's infringement decision issued in this case (including concerning abuse of dominant position) or (ii) allocating fines imposed on infringers jointly and severally and (iii) if it is necessary for this party's defence. The ECN+ Directive extends the application of those rules to purely domestic cases (the only such instance in the entirety of its text).

Additionally, the party may not use in courts information obtained during the NCA's enforcement proceedings, which was prepared (i) by other persons specifically for the purposes of this proceedings or (ii) by the NCA and sent to the parties in the course of such proceedings. ${ }^{116}$ In this case, the restriction is temporal and lasts until the NCA terminates the enforcement proceeding with respect to all of the parties (by an infringement or commitment decision or otherwise).

Any of the above is without prejudice to the possibility of a NCA to publish the infringement decision that includes some leniency information ${ }^{117}$ and applies independently of the form in which corporate leniency statements was submitted.

In Poland ${ }^{118}$, only the parties to the proceedings may access leniency information (corporate statements and those submitted by individuals and other leniency-related material) in the file of the Polish NCA. ${ }^{119}$ The information may be accessed after the Polish NCA issues a statement of objections; until this point of time, the parties should not even be aware that a leniency

116 As well as withdrawn settlement submissions. This provision extends the protection availed in Article 6(5-6) of the Damages Directive.

117 Article 31(7) and Recital 72 of the ECN+ Directive and recital 26 if the Damages Directive. Szot, 2018, p. 99-103, discusses in the context of Evonik judgment the rules governing the use of leniency information in the public version of the infringement decisions.

118 See Article 70, 73 and of the 2007 Competition Act. Piszcz, 2016, p. 217, perceived protection availed by those provisions as overly broad and pointed out that it disregards interests of claimants in private enforcement actions and the related EU case law (comments were made prior to the implementation of the Damages Directive).

119 According to Article 70(6) of the 2007 Competition Act, those documents and information cannot be made available based on public transparency rules (Act of 6 September 2001 on access to public information (Journal of Laws 2019, item 1429). 
application was submitted (Krueger, 2016, p. 913). ${ }^{120}$ The parties may not copy any leniency statements but may take notes, provided they stipulate not to use them otherwise than for the purposes of exercising their right of defence ${ }^{121}$ in this enforcement proceeding or in follow-on judicial review proceedings. ${ }^{122}$ The applicant may consent to a disclosure or to the making of copies. Breach in that regard (copying without consent or improper use, except in penal proceedings) by anyone, not only the parties to the proceedings, is sanctioned with a penalty of up to approx. EUR 5000. The low amount of this fine renders this protection rather illusionary (Article 108(5) of the 2007 Competition Act; see Stawicki and Komorowska, 2016, p. 1437). However, evidence obtained in this manner, or information obtained owning to access to leniency statements, may not be used as evidence in other court proceedings. ${ }^{123}$

Those provisions ensure (i) access restrictions - only the parties to the relevant proceedings (before the NCA or reviewing court) have access to the leniency statements, however the applicant's consent may remove this restriction. (ii) Use restrictions: normally, the parties may not use information obtained in this manner otherwise than for the purposes of their defence, but the limitation is not absolute (it applies to notes and unauthorised copies but not to the information as such and authorised copies). There are no temporal restrictions on the use in courts by the parties of other information (Polish NCA's official letters and information prepared by others for the proceedings before the Polish NCA). The ECN+ Directive provides for firm and general access and use restrictions. Hence, the implementation of it requires removing the consent option and prohibiting the use of information derived from leniency statements (at least in cartel cases) otherwise than for the exercise of the right of defence as well as introducing temporal use limitations of other material, for example, by amending the provisions discussed above.

120 The parties may, however, learn that a leniency application was submitted in the proceedings indirectly, i.e. by way of confirmations that they should receive if they decide to submit their own leniency applications, see comments in Section V.3 above).

121 This purpose is not directly specified in the relevant provision but is self-evident.

122 Same applies to statements in the review court's files. Additionally, making leniency statements available for the purposes of other judicial proceedings is subject to the consent of the given leniency applicant (Article $479^{33}$ para. 2a, 2b and 6 of the Civil Procedure Code).

123 Article $479^{33}$ para. $2 \mathrm{~b}$ of the Civil Procedure Code. The wording of this provision is unclear: it justifies either (i) a broad reading: never an unauthorised copy of a leniency statement or information derived from leniency statements can be used in civil courts other than a reviewing court or (ii) narrower: it prohibits the use of unauthorised copies of leniency statements and information derived from such copies and solely if such copies where obtained from the court files (excluding other files). Stefańska, 2015, Article 47933, indirectly endorsed a reading suggesting that the provision concerns only the documents placed in the court files. Other commentaries were inconclusive (Telenga, 2019; Ereciński, 2016). 
Broader protection of leniency statements in Poland (namely those covering other than cartel infringements and leniency statements from individuals) do not conflict with the ECN+ Directive. However, the implementation will require important amendments in another aspect. Polish law allows to use the information from the Polish NCA's file for the purposes of other proceedings before the Polish NCA, in penal proceedings (instituted by public prosecutors, including in tax matters), private enforcement proceedings (with limitations steaming from the Damages Directive), or by the competent authorities in any other enforcement proceedings ${ }^{124}$ as well as to exchange them with the Commission and other NCAs pursuant to Regulation 1/2003/EC (Article 12(2) and 22(1)) and Regulation 2006/2004/EC 125 (Article 6 and 7). Those very broad exceptions provided for in Article 73(1)-(2) of the 2007 Competition Act undermine the access restrictions to (cartel) leniency statements that the $\mathrm{ECN}+$ Directive purports to impose. ${ }^{126}$

Currently, the Damages Act ensures that leniency statements are not disclosed or used in the context of private enforcement and imposes temporal use limits on other material. ${ }^{127}$ However, the exemption allowing the use of information steaming form leniency statements in penal and other enforcement proceedings should be removed at least with respect to corporate statements in cartel cases. ${ }^{128}$ Unfortunately, it does not seem that the ECN+ Directive disqualifies the use of those materials for the purposes of NCA's other proceedings (or addresses the exchange based on the Regulation 2006/2004, see critical comments in Section VI below). Hence, the former exception may remain intact. The exchange of corporate leniency statements pursuant to Article 12 of Regulation 1/2003 should be allowed only if the applicant

124 Article 73 (2) of the 2007 Competition Act. Prior to the implementation of the Damages Act, it was unclear if civil courts could use this provision to access the files of the Polish NCA, in particular Article 73 (2) para. 5 referring to 'the competent authorities in any other enforcement proceedings' (in favour Jurkowska-Gomułka, 2013, p. 222; against: Bernatt, 2015). Błachucki, 2015, p. 19 points out that in practice the Polish NCA did not allow the requests of the civil court based on the latter provision (those requests were, however, unrelated to private enforcement).

125 Regulation (EC) No 2006/2004 of the European Parliament and of the Council of 27 October 2004 on cooperation between national authorities responsible for the enforcement of consumer protection laws (the Regulation on consumer protection cooperation), (OJ L 364, p. 1-11), hereinafter: Regulation 2006/2004. For comments relating to the Regulation 2006/2004 and 2007 Competition Act see Król-Bogomilska, 2009, p. 5.

126 See comments in the Impact Assessment Report, p. 64-65.

127 Articles 18 and 29 of the Damages Act, discussed by Szot, 2017, p. 93-95 and Jurkowska-Gomułka, 2018, comments to Article 18 and 29.

128 This would in fact require introducing protection comparable to Article 89a(12) and corresponding amendments of Article 108(5) of the 2007 Competition Act. 
consents to such exchange or it submitted a leniency application also to the receiving authority and may not withdraw it at the time when such exchange is affected (as expressly specified in Article 31(6) of the ECN+ Directive). Extending the consent requirement also to cooperation in consumer cases baes on Regulation 2006/2004 appears to be a logical addition.

\section{Missed opportunities}

There is a number of important problematic issues relating to leniency that the ECN+ Directive failed to address. Due to space constraints, only the main problems are briefly discussed below.

Firstly, the most severe criticism of the ECN+ Directive in the context of leniency (and perhaps in general) is that it failed to introduce a one-stop-shop system. Instead it continues to relay on summary applications. The latter is only a partial solution to problems that applicants in multijurisdictional cases face when considering leniency applications ${ }^{129}$ (although extending summary application options to applicants requesting the Commission to reduce their fines is a positive change). A system based on summary application will not provide automatic protection across the EU, in particular that the applicant must ensure that the scope of the application before the Commission and before the NCAs are convergent at all times. Importantly, it does not provide any relief to applicants who submit applications in more than one jurisdiction but not before the Commission (for example, because they apply for leniency with respect to non-cartel infringements). Such applicants will still have to apply simultaneously to all relevant NCAs, because an application filed with one NCA is not recognised elsewhere. Multiple applications will be required irrespectively of the fact which NCA at the end of the day will decide to pursue the matter. ${ }^{130}$ The possibility to request a marker will be of some help in this event. However, it does not mend the problem entirely, since the NCAs will enjoy now the discretion to accept or reject marker requests.

Secondly, the situation was not made any easier be the fact that no language that could be used universally was selected upfront in the ECN+ Directive. Such option could be at least ensured with respect to corporate statements

129 See Król-Bogomilska, 2012, p. 9; Król-Bogomilska, 2018, p. 22; Wagner-von Papp, 2019 , p. 7.

130 More than one NCA may have formally jurisdiction over the case but out of efficiency concerns only some may decide to pursue the investigation (Blake and Schnichels, 2004, p. 11). 
(Wagner-von Papp, 2019, p. 8). An applicant will have instead only a possibility to agree with the NCA on the specific language version, which may lead to undesired delays and uncertainty.

Thirdly, the failure to harmonise the approach towards leniency applications relating to non-cartel infringements is an important drawback (that is, in terms of leniency conditions or rules on access to non-cartel leniency materials). Król-Bogomilska, 2018, p. 20, emphasised that inconsistences in that regard may produce equally deterrent effects on potential applicants and so undermine the enforcement of competition law.

Fourthly, the ECN + Directive does not specify the manner in which the fine should be reduced or relevant redaction criteria. It does not even provide for a maximum reduction threshold that would ensure that there is a clear difference between immunity and a fine reduction, and hence incentivise the infringers to report as early as possible. The MLP sets 50\% threshold in this respect in paragraph 11 (see also paragraph 24 of the MLP explanatory notes). Nor does the ECN+ Directive determine the impact that the rejection of an application or disqualification from the benefits at the end of the proceedings has on the place in the queue of others. The lack of clarity concerning the level of potential fine discounts, and shifts in the queue, are important drawbacks. These are undoubtedly important decision-making factors. Uncertainties concerning the scope and nature of potential advantages in different jurisdictions may have deterrent effects that the ECN+ Directive purports to remove.

Fifthly, the ECN+ Directive does not prohibit the use of information steaming form leniency statements for the purposes of a NCA's proceedings other than the one relating to the reported infringement. This considerably undermines the use restrictions already envisaged (see Section V.7 above).

Sixthly, the ECN+ Directive does not specify if the NCA has the duty to grant the leniency benefits if the applicant fulfils all of the specific and general conditions. ${ }^{131}$ This is yet another drawback. It does not make sense to lay down detailed requirements regarding conditions for granting leniency advantages without deciding whether the applicant's right in this regard is something more than a legitimate expectation. After all, uncertainty in this respect is an important factor that undermines an applicant's confidence. Recourse to an obligation to effectively enforce the application of Article 101 TFEU may

131 The Member States are under an obligation to have LPs in place that enable them to grant immunity from or reduction of fines (Article 17(1) and 18(1)). It does not mean that such benefits shall be granted. 
help to overcome this problem, ${ }^{132}$ however lack of clarity and certainty is undesirable.

Lastly, the ECN+ Directive failed to introduce an unequivocal requirement to provide for automatically applicable immunity from sanctions that can be imposed on individuals in criminal proceedings. Instead, the ECN+ Directive leaves the option open for Members States to provide for a system that allows lifting the sanctions or mitigating them ex-post (Article 23(3)). That is, it is for the authority in charge of criminal proceeding to decide whether at the end a given individual's contribution to discover the cartel outweighed the interest in imposing criminal sanctions upon him or her. As Wagner-von Papp, 2019, p. 8 emphasised, the existence of such systems will undermine the incentives to come clean in multijurisdictional matters entailing possible criminal liability, most notable in cases of bid rigging. The applicants will continue to be unsure whether penal sanctions will be eventually imposed or not.

\section{Conclusions}

The PLP, owing to earlier informal harmonisation with the MLP and EU notices, corresponds in broad terms to the requirements of the ECN+ Directive. A number of adjustments is nonetheless needed, in particular if a maximum harmonisation approach is endorsed. The implementation will, in the majority of cases, require amending the 2007 Competition Act or the 2014 Procedural Regulation. Some principles are already reflected in the Polish NCA's practice. They will have to be transposed into bind law, as the practice may always change.

The main examples of the required modifications concern (i) specific conditions for immunity (in particular motion of relevant evidence or ring-leaders and deleting the concept of relevant information), (ii) providing for partial immunity, (iii) narrowing down the scope of Leniency Plus, (iv) adjustments concerning admissibility of leniency statements in languages other than Polish, (v) making granting of a marker subject to the Polish NCA's discretion, (vi) extending availability of summary applications to undertakings applying for a reduction of fines or submitting markers. Most notable amendments concern, however, (vii) linking corporate immunity with an immunity for natural persons from penal sanctions (or at least alleviating such liability) and (viii) broadening the protection of leniency statements. As explained, the latter cover permanent access restrictions as well as internal (by the parties) and external (by other enforcers) use restrictions of leniency

132 In the sense that inconsistent approach to applications may weaken the efficiency of the whole programme and adversely impact the enforcement of Article 101 TFEU. 
statements and temporal use restrictions applicable to materials specifically related to the leniency.

The two last issues (broader protection of leniency materials and mitigating penal sanctions) seem to have the greatest capacity to enhance antitrust enforcement, especially if immunity for bid-riggers is endorsed. Additionally, if the threshold 1 relevant evidence clearly refers to the evidence enabling the targeted inspection (instead of evidence enabling lunch of full-fledged investigation) the applicants could be finally motivated to come clear earlier. Nowadays, the prevailing practice is to request leniency only after the Polish NCA commenced the dawn raid. Apart from them, the changes will not revolutionise the functioning of the PLP or visibly boost its efficiency, in particular regarding combating cartels. The reason behind this conclusion is two-fold. Firstly, effectiveness of cartel detection in Poland is generally low. The authorities invest scarce resources on investigating vertical restraints or pursuing competition unrelated and ever-growing obligations imposed by law. Improvements in this regard are indispensable, including shifting the enforcement priorities in real terms. Secondly, perhaps other, non-leniency related solutions in the ECN+ Directive will help to strengthen antitrust enforcement to certain extent (for instance those obliging Member States to ensure the NCAs with sufficient resources and autonomy). In terms of the leniency area, the critics argue that Union legislators missed an opportunity to mend some very compelling problems. These are such issues as (i) making multijurisdictional leniency applications easier by introducing an EU-wide one-stop-shop, (ii) agreeing on an uniformly acceptable language version or (iii) unequivocally regulating the interplay between leniency protection and individual sanctions imposed on natural persons. In the latter case, providing for a clear cut duty to secure immunity from criminal sanctions would be a welcome development. Other harmonisation flaws include (iv) lack of determining the impact on the queue order of rejections, withdrawals and disqualifications, (v) a complete absence of rules (or guidelines) concerning fine reductions, (vi) failure to determine whether the NCAs enjoy discretion to grant leniency and (vii) completely excluding from harmonisation non-cartel infringements. These and other deficiencies undermine the $\mathrm{ECN}+$ Directive's ability to advance current enforcement standards in real terms.

Implementation will be also a good occasion to overhaul the PLP in other areas, for example, properly defining 'coercers', scaling-down the scope of leniency benefits to cartels, hub and spoke, bid-rigging and vertical pricing infringements or sorting legal definitions (of leniency application or cartels) and providing in a clear manner which provisions of the 2014 Procedural Regulations apply also to markers and summary applications. 


\section{ANNEX 1}

Table 1. Comparison of requirements relating to relevant evidence and relevant information pursuant to the PLP and ECN+ Directive

\begin{tabular}{|l|}
\hline \multicolumn{1}{|c|}{ PLP } \\
\hline \multicolumn{1}{|c|}{ I. IMMUNITY } \\
\hline a) Threshold 1 relevant evidence: \\
\hline $\begin{array}{l}\text { Article 113b(2)a: Evidence that enables the Polish } \\
\text { NCA to launch a full-fledged investigation or }\end{array}$ \\
\hline b) Threshold 1 relevant information: \\
\hline $\begin{array}{l}\text { Article 113b(2)a: information that enabled the Pol- } \\
\text { ish NCA to collect such evidence, provided the Polish } \\
\text { NCA was not, at that time, in possession of this infor- } \\
\text { mation or evidence } \\
\text { (Polish: dowód wystarczajacy do wszczecia postepowania } \\
\text { antymonopolowego lub informacje umożliwiajace Pre- } \\
\text { zesowi Urzędu uzyskanie takiego dowodu, o ile Prezes } \\
\text { Urzędu nie posiadat } w \text { tym czasie tych informacji lub } \\
\text { dowodów albo) }\end{array}$ \\
\hline
\end{tabular}

a) Threshold 2 relevant evidence:

Article $113 b(2)$ b: Evidence that significantly contributes to finding of an infringement (if such investigation was already launched) or

\section{b) Threshold 2 relevant information:}

Article 113b(2)b: on the Polish NCA's request submitted information that enabled the Polish NCA to collect such evidence, provided the Polish NCA was not, at that time, in possession of this information or evidence

(Polish: jeżeli wniosek zostat złożony po wszczęciu postępowania antymonopolowego - dowód, który $w$ istotny sposób przyczyni się do wydania decyzji, o której mowa $w$ art. 10, lub na żadanie Prezesa Urzędu przedstawit informacje umożliwiajace uzyskanie takiego dowodu, o ile Prezes Urzędu nie posiadat $w$ tym czasie tych informacji lub dowodów)

Article 17.2(c)(i): Evidence that enables the NCA to carry out a targeted inspection (in connection with a secret cartel), or

ECN+ Directive

(1)




\section{Bibliography}

Bernatt, M., Turno, B. (2015). O potrzebie doskonalenia rozwiązań procesowych w znowelizowanej z dniem 18 stycznia 2015 r. ustawie o ochronie konkurencji i konsumentów. internetowy Kwartalnik Antymonopolowy i Regulacyjny, 2(4), 75-92.

Bernatt, M. (2015). Komentarz do art. 73 ustawy o ochronie konkurencji i konsumentów. In: T. Skoczny (ed.), Komentarz do ustawy o ochronie konkurencji i konsumentów. Warszawa: Legalis.

Blake, S., Schnichels, D. (2004). Leniency following Modernisation: safeguarding Europe's leniency programmes. Competition Policy Newsletter, 2, 7-13.

Błachucki, M. (2015). Dostęp do informacji przekazywanych Komisji Europejskiej i Prezesowi UOKiK w trakcie procedury łagodzenia kar pieniężnych (leniency). Europejski Przeglad Sadowy, 5.

Dobosz, K., Scheibe, M. (2017). Pierwsze uwagi i wątpliwości po przedstawieniu projektu antymonopolowej dyrektywy efektywnościowej. Przeglad Prawa Publicznego, 6, 99-110.

Ereciński, T. (2016). Komentarz do Art. 479(33). In: T. Ereciński (ed.), Kodeks postępowania cywilnego. Komentarz. Tom III. Postępowanie rozpoznawcze, wyd. V edition. Warsaw: Wolters Kluwer Polska.

Gauer, C., Jaspers, M. (2007). ECN Model Leniency Programme - a first step towards a harmonised leniency policy in the EU. Competition Policy Newsletter, 1, 35-38.

Hansberry-Bieguńska, D., Krasnodębska-Tomkiel, M., Materna G. (2016). Programy łagodzenia kar w polskim i amerykańskim prawie ochrony konkurencji a dostępność materiałów leniency dla osób dochodzących roszczeń odszkodowawczych w sprawach karteli i antykonkurencyjnych porozumień. Internetowy Kwartalnik Antymonopolowy i Regulacyjny, 5(5), 20-57;

Jurkowska-Gomułka, A. (2018). Komentarz do Art. 18, 29. In: A. Piszcz (ed.), A. Stawicki (ed.), Roszczenia o naprawienie skody wyrzadzonej przez naruszenie prawa konkurencji. Komentarz, first ed., Warsaw: Wolters Kluwer Polska.

Jurkowska-Gomułka, A. (2013). Publiczne i prywatne egzekwowanie praktyk ograniczajacych konkurencję. Warszawa: Wydawnictwo Naukowe Wydziału Zarządzania Uniwersytetu Warszawskiego.

Korycińska-Rządca, P. (2018). Europeanisation of the Polish Leniency Programme. Yearbook of Antitrust and Regulatory Studies, 11(18), 61-83; DOI: 10.7172/1689-9024. YARS.2018.11.18.3.

Kowalik-Bańczyk, K. (2014). Ways of Harmonising Polish Competition Law with the Competition Law of the EU. Yearbook of Antitrust and Regulatory Studies, 7(9), 141-159.

Król-Bogomilska, M. (2018). Kary pieniężne w prawie antymonopolowym w świetle projektu dyrektywy służącej zwiększeniu skuteczności egzekwowania reguł konkurencji (COM(2017) 142 final). EPS, 1, 12-23.

Król-Bogomilska, M. (2015). Najnowsze zmiany w zakresie sankcji penalnych w polskim prawie antymonopolowym a prawo unijne - kolejne podobieństwa i różnice. EPS, 7, 4-12.

Król-Bogomilska M. (2012). Program łagodzenia kar (leniency) w polskim prawie antymonopolowym - po pięciu latach obowiązywania ustawy. EPS, 4, 4-10.

Król-Bogomilska, M. (2010). Kary pieniężne - główne kierunki ewolucji w okresie 20 lat rozwoju polskiego prawa antymonopolowego. EPS, 5, 5-14.

Król-Bogomilska, M. (2009). Kierunki najnowszych zmian polskiego prawa antymonopolowego. EPS, 6, 4-12. 
Kulesza, M. (2015). Leniency - the Polish Programme and the 'Semi-formal' Harmonisation in the EU by the European Competition Network. Yearbook of Antitrust and Regulatory Studies, 8(11), 83-100; DOI: 10.7172/1689-9024.YARS.2018.11.18.3.

Krueger, J. (2016). Komentarz do Art. 70-73. In: A. Stawicki (ed.), S. Stawicki (ed.), Ustawa o ochronie konkurencji i konsumentów. Komentarz, wyd. II, Warsaw: Wolters Kluwer Polska.

Martyniszyn, M. (2015). Leniency (Amnesty) Plus: A Building Block or a Trojan Horse?. Retrieved from: https://www.researchgate.net/publication/266143728_Leniency_ Amnesty_Plus_A_Building_Block_or_a_Trojan_Horse (30.06.2019).

Materna, G. (2018). Projekt dyrektywy $\overline{\mathrm{ECN}}+$ (omówienie w aspekcie potrzeby kolejnej nowelizacji polskiego prawa ochrony konkurencji) internetowy Kwartalnik Antymonopolowy i Regulacyjny, 2(7), 31-39; DOI: 10.7172/2299-5749.IKAR.2.7.3.

Modzelewska-Wąchal, E. (2014). Komentarz do artykułu 113e i 113f. In: T. Skoczny (ed.), Ustawa o ochronie konkurencji i konsumentów. Komentarz. Warszawa: C.H. Beck.

Molski, R. (2014). Komentarz do artykułu 113a-113c. In: T. Skoczny (ed.), Ustawa o ochronie konkurencji i konsumentów. Komentarz. Warszawa: C.H. Beck.

Monti, G. (2017). ECN Plus Directive: Empowering NCAs? Strengthening the network? Retrieved from:

Piszcz, A. (2016). A Note on 2015 Developments in Polish Competition Law: Is it Really a Drive Towards the European Model? Yearbook of Antitrust and Regulatory Studies, 9(14), 203-225, DOI: 10.7172/1689-9024.YARS.2016.9.14.10.

Piszcz, A. (2015). Nowe elementy regulacji prawnej kar pieniężnych w ustawie o ochronie konkurencji i konsumentów. Internetowy Kwartalnik Antymonopolowy i Regulacyjny, 2(4), $42-58$.

Piszcz, A. (2013). Osoba zarządzająca w rządowym projekcie ustawy zmieniającej ustawę o ochronie konkurencji i konsumentów. internetowy Kwartalnik Antymonopolowy i Regulacyjny 7(2), 23-30.

Rumak, E. and Sitarek, P. (2009). Polish Leniency Programme and its Intersection with Private Enforcement of Competition Law. Yearbook of Antitrust and Regulatory Studies, 2(2), 99-123; DOI: 10.7172/1689-9024.YARS.2018.11.18.3.

Rusu, C.S. (2017). The Commission's 2017 EU Antitrust Draft Directive: Addressing the Public Enforcement Fragmentation. Retrieved from: https://www.ru.nl/law/research/ radboud-economic-law-conference/radboud-economic-law-blog/2017/commission2017-eu-antitrust-draft-directive/ (30.06.2019).

Semeniuk, P. and Syp, S. (2013). „Wylanie dziecka z kąpielą” - czyli o leniency plus w Polsce. Internetowy Kwartalnik Antymonopolowy i Regulacyjny, 7, 31-41.

Sitarek, P. (2014). The Impact of EU Law on a National Competition Authority's Leniency Programme - the Case of Poland. Yearbook of Antitrust and Regulatory Studies, 7(9), $185-216$.

Skoczny, T. (2015). 2014 Amendment of the Polish Competition and Consumers Protection Act 2007. Yearbook of Antitrust and Regulatory Studies, 8(11), 165-183.

Sołtysiński, S. (2004). Z doświadczeń programu leniency w Brukseli i w Warszawie. In: C. Banasiński (ed.). Prawo konkurencji - stan obecny i przewidywane kierunki zmian, Warsaw: Urząd Ochrony Konkurencji i Konsumentów.

Stawicki, A., Komorowska, P. (2016). Komentarz do Artykułu 108. In: A. Stawicki, S. Stawicki (ed.), Ustawa o ochronie konkurencji i konsumentów. Komentarz, wyd. II, Warsaw: Wolters Kluwer Polska. 
Stephan A. (2011). ECJ Ruling in Pfleiderer Heightens Concerns about Encouraging Private Enforcement. Retrieved from: https:/competitionpolicy.wordpress.com/2011/06/23/ ecj-ruling-in-pfleiderer-heightens-concerns-about-encouraging-private-enforcement/ (30.06.2019).

Stefańska, E. (2015). Komentarz do Artykułu 47933. In: M. Manowska (ed.), Kodeks postępowania cywilnego. Komentarz. Tom I. Art. 1-505(38), third edition, Warsaw: Wolters Kluwer Polska.

Szot, P. (2018). Czy informacje dostarczone przez wnioskującego o leniency mogą pojawić się w wersji jawnej decyzji stwierdzającej naruszenie? Glosa do wyroku TS z 14 marca 2017 r. w sprawie C-162/15 P Evonik Degussa GmbH przeciwko Komisji. internetowy Kwartalnik Antymonopolowy i Regulacyjny, 2(7), 89-106.

Szot, P. (2017). Ułatwienia dowodowe i rozpoznawania spraw w projekcie ustawy o roszczeniach o naprawienie szkody wyrządzonej przez naruszenie prawa konkurencji. internetowy Kwartalnik Antymonopolowy i Regulacyjny, 6(1), 80-101.

Telenga, P. (2019) Komentarz do Art. 47933. In: A. Jakubecki (ed.), Kodeks postepowania cywilnego. Komentarz aktualizowany. Tom I. Art. 1-729. LEX/el. 2019

Turno, B. (2016). Komentarz do Art. 113a-113k. In: A. Stawicki (ed.), S. Stawicki (ed.), Ustawa o ochronie konkurencji i konsumentów. Komentarz, second edition, Warsaw: Wolters Kluwer Polska.

Turno, B. (2013). Leniency. Program tagodzenia kar pieniężnych w polskim prawie ochrony konkurencji, first ed., Warsaw: Wolters Kluwer Polska.

Wagner-von Papp, F. (2019). Directive of the European Parliament and of the Council to empower the competition authorities of the Member States to be more effective enforcers and to ensure the proper functioning of the internal market ("ECN Plus Directive"). Retrieved from: https://www.competitionpolicyinternational.com/wp-content/uploads/2019/01/ EU-News-Column-January-2019-3-Full.pdf (30.06.2019). 